بررسى تأثير توسعه محصول جديد سبز بر عملكرد اتتصادى سازمان با رويكرد

\title{
يويايى سيستمها
}

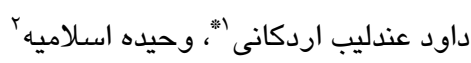

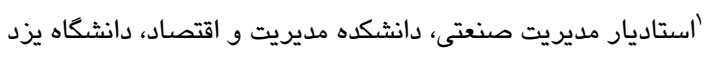

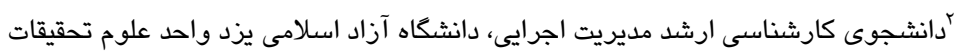

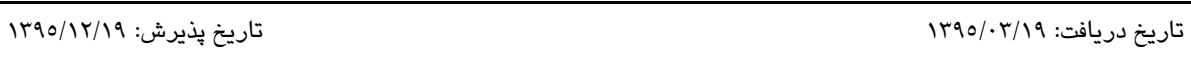

جִ جيده

با توجه به اينكه سازمانهاى امروزى در محيط بِيجيده فعاليت مىكنتد ناكزيرند تا بهطور

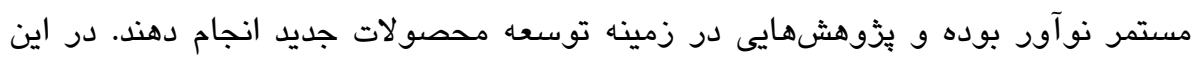

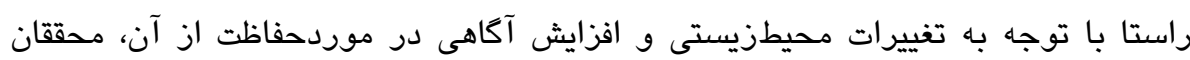

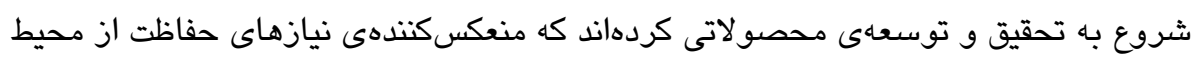

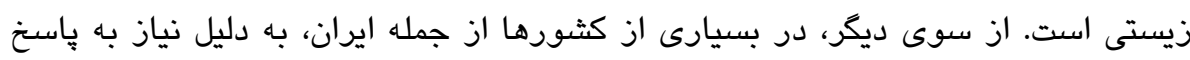

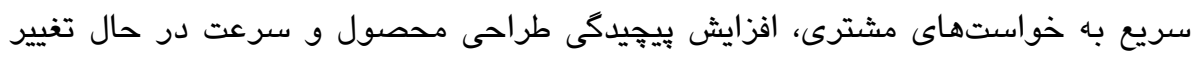

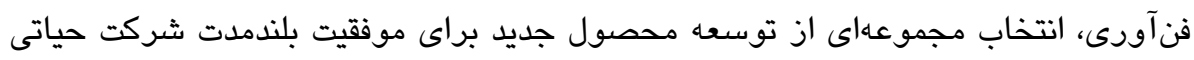

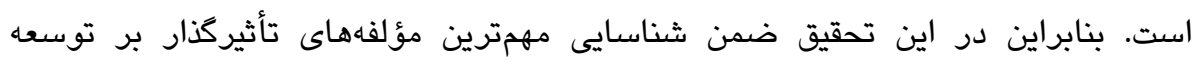

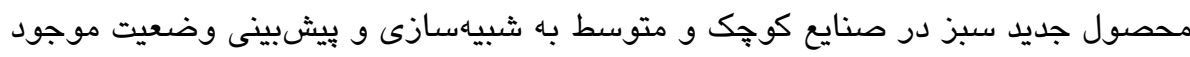

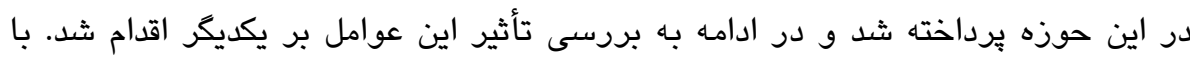

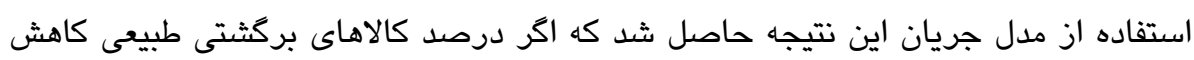

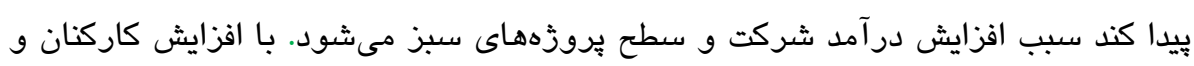

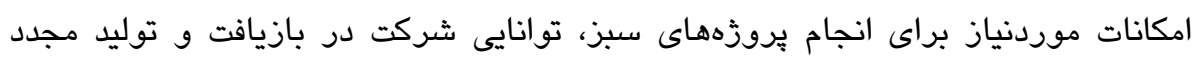

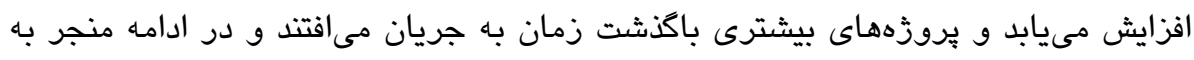

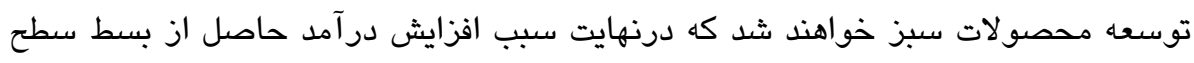

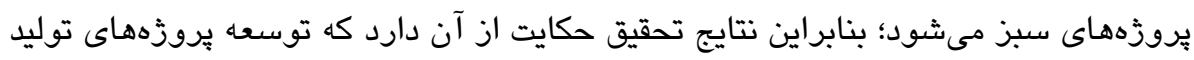

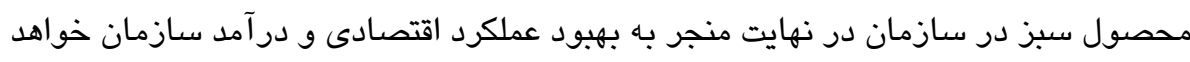

كلمات كليدى : توسعه بِيدار، توليد سبز، عملكرد اقتصادى، بويايى سيسترها

Email: davood.andalib@gmail.com : نويسنده مسئول-" 
مقدمه

در محيط بازار رقابتى امروز، سازمانها بهطور فزايندهاى با جالش بهبود و معرفى

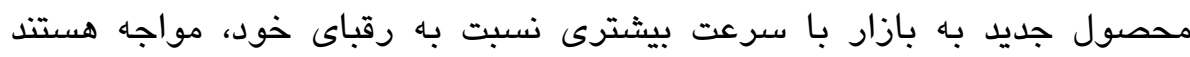

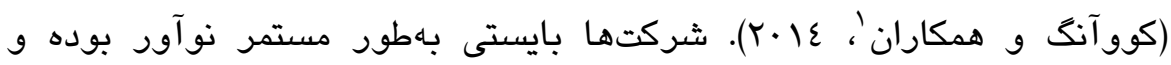
يخوهشهايى در زمينه محصولات جديد ترتيب دهند و محصولاتى را انتخاب نمايند

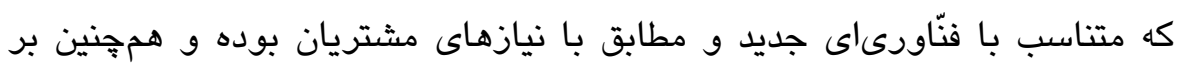

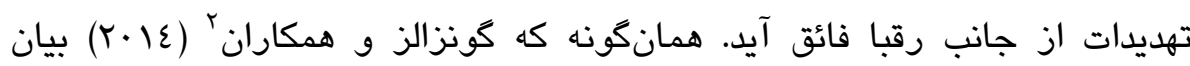

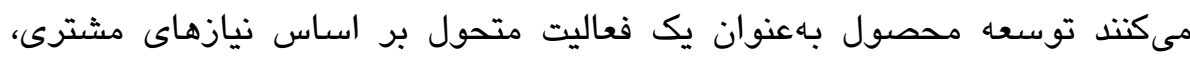
استراتزى سازمانى و محيط داخلى و خارجى تعريف مىشود.

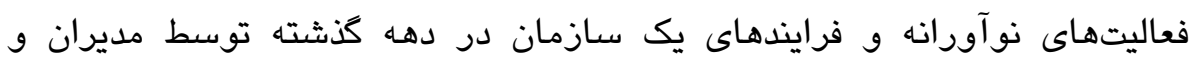

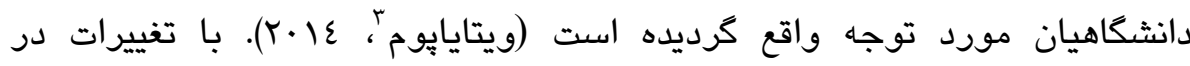

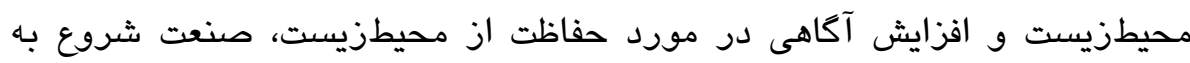
تحقيق و توسعه كه منعكسكنتده نيازهايى براى حفظ محيطزيست است، كرده و مورد

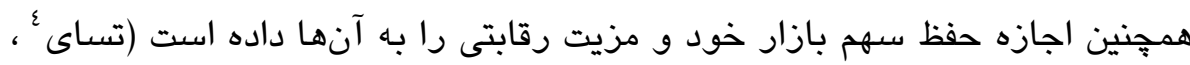

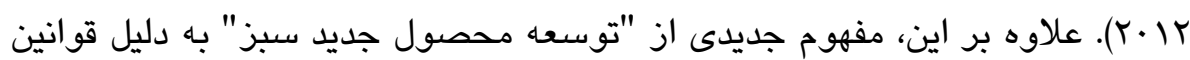

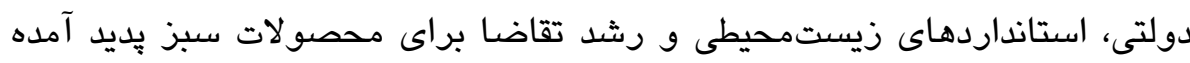

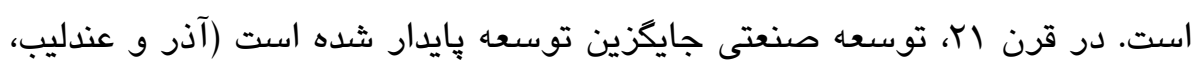

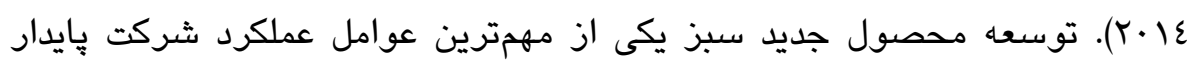

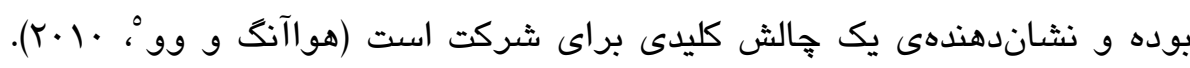

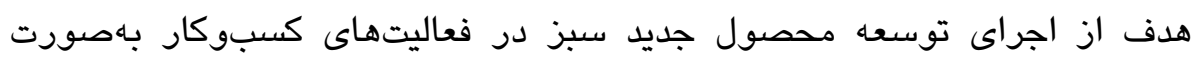

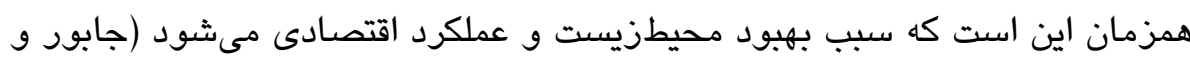

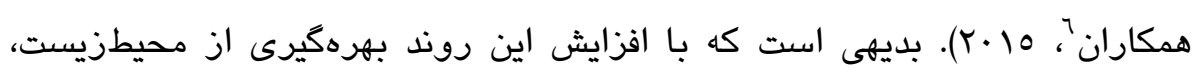

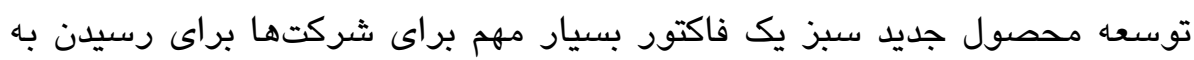

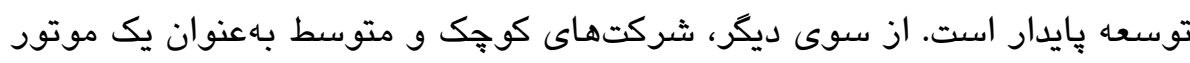

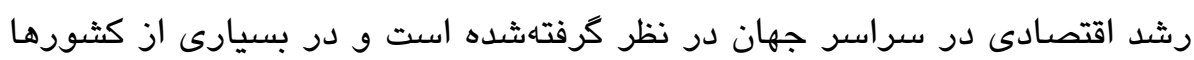

1- Kowang

2- González

3- Wittayapoom

4- Tsai

5- Huang \&Wu

6- Jabbour 
ازجمله ايران، به دليل نياز به پاسخخ سريع به نيازهاى مشترى، افزايش بِيجِيدكى

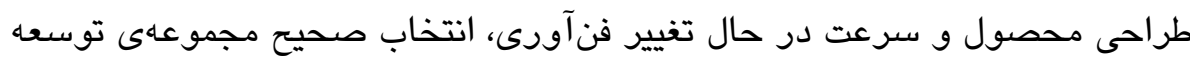
محصول جديد جهت موفقيت طولانىمدت براى شركت بسيار حياتى مىباشد. از اين

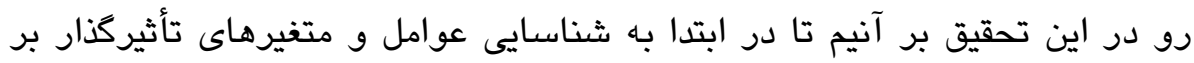
توسعه محصول جديد سبز در صنايع كوجك و متوسط بيردازيم. در ادامه با استفاده از فن يويايى سيستمها ضمن شبيهسازى وضعيت موجود سبز بودن توسعه

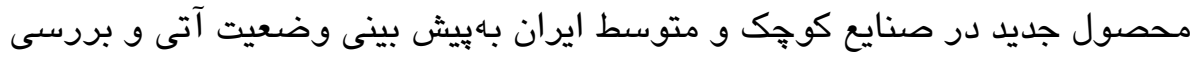
تأثير عوامل مؤثر بر توسعه محصول جديد سبز در اين حوزه بيردازيم.

\section{مبانى نظرى تحقيق توسعه محصول جديد سبز}

در طول جند دهـه كذشته، شركتها ملاحظات زيستمحيطى را در استراتزىهاى

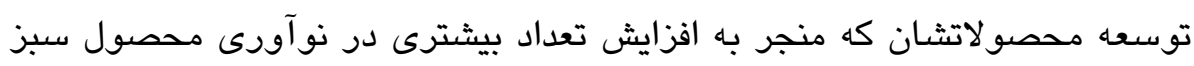

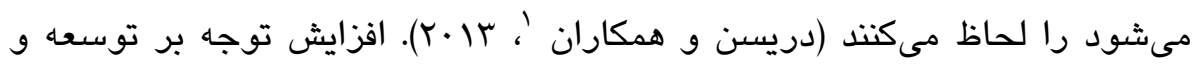

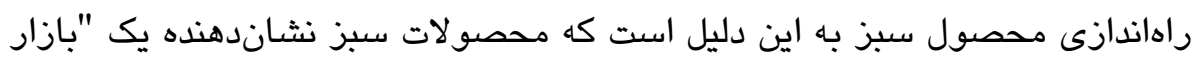

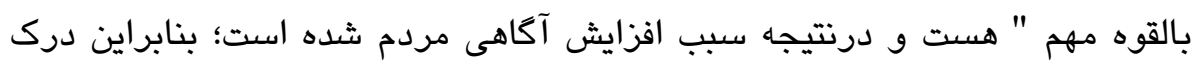

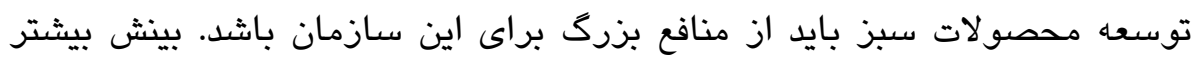

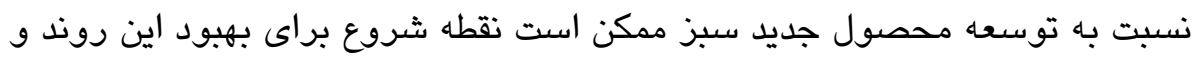

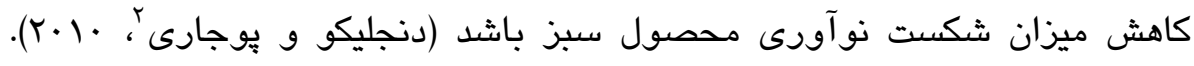

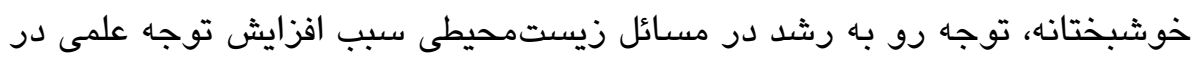
توسعه محصول جديد سبز، بهويزه در ادبيات مديريت زيستمحيطى شده رون است

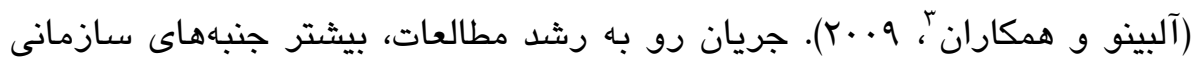

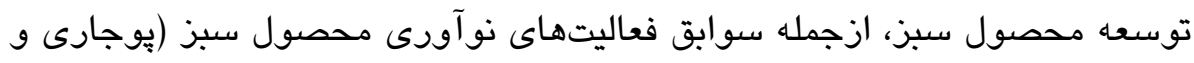

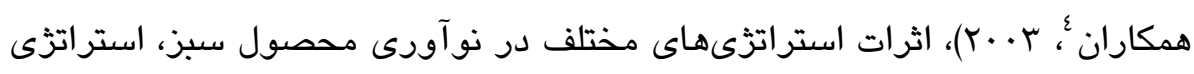

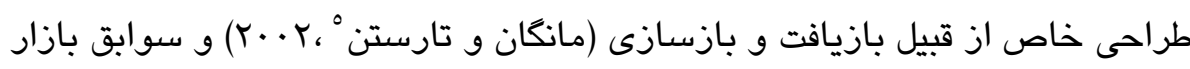
بازار و عملكرد زيستمحيطى نوآورى محصول سبز را بررسى كرده است است. امروزه،

1- Driessen

2- Dangelico \& Pujari

3- Albino

4- Pujari

5- Mangun\& Thurston 
افزايش بحث و علاقه به توسعه محصول سبز بهوضوح مشاهده مىشود و توسعه

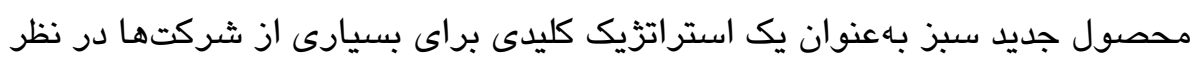

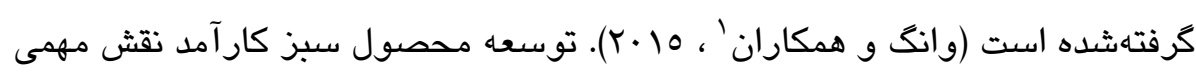

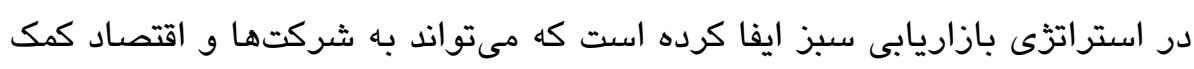

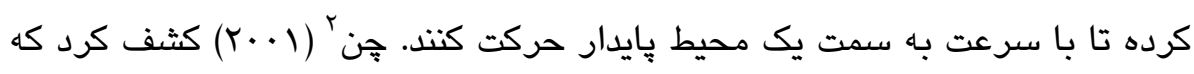

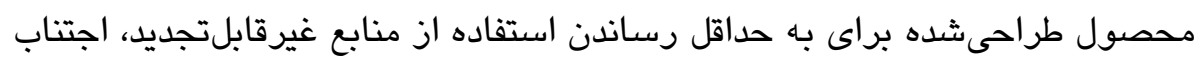

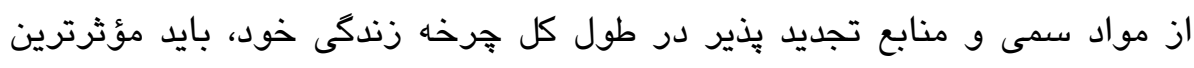

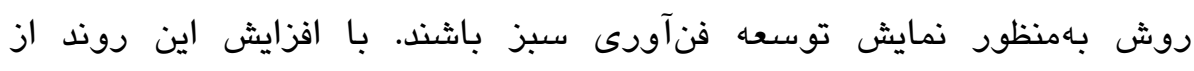

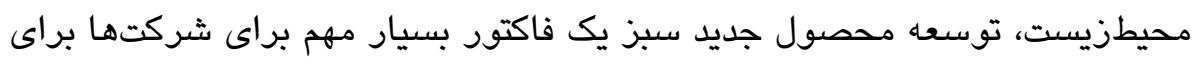

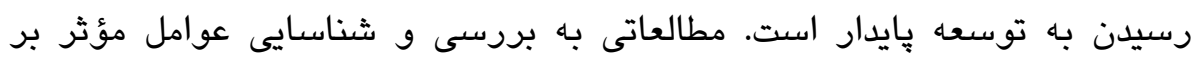

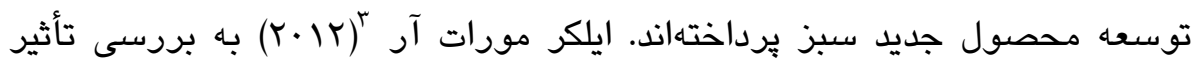

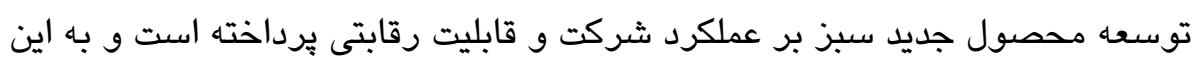

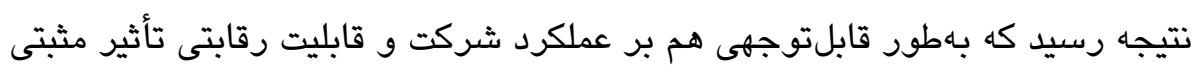

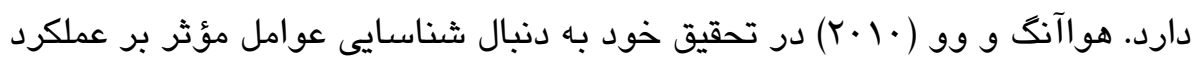

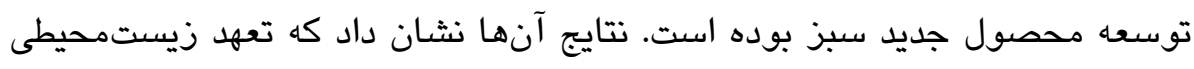

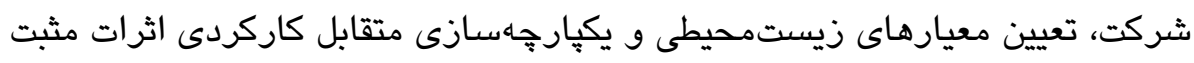

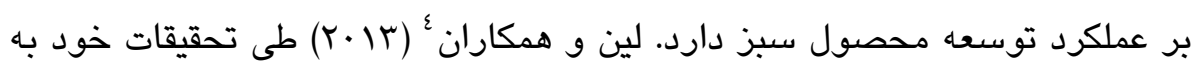

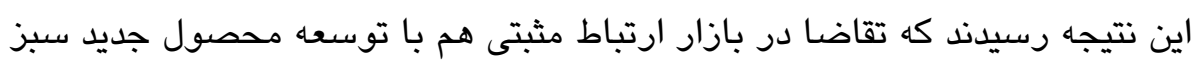

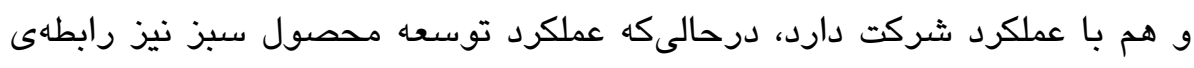
مثبتى با عملكرد شركت دارد.

\section{مزاياى استفاده از بازاريابى سبز و توسعه محصول سبز}

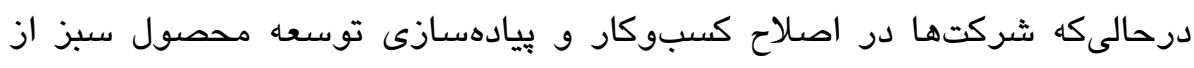

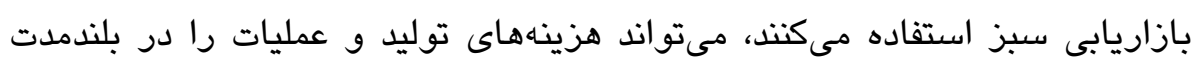

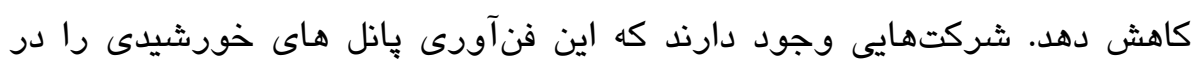

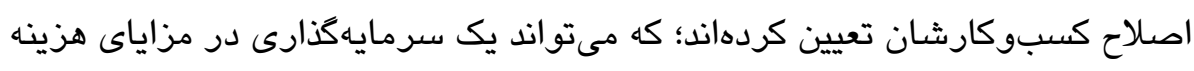

1- Wang

2- Chen

3- Ar, Ilker Murat

4- Lin 


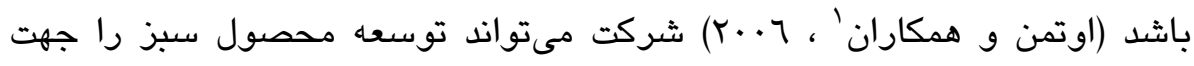

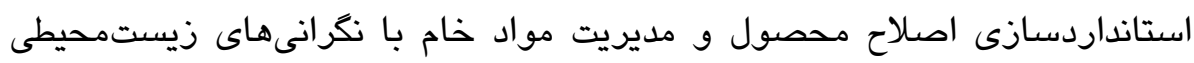
تمرين دهد، درنتيجه، سبب كاهش اثرات منفى بر سلامت انسان و محيطزيست مديت مولى بـات

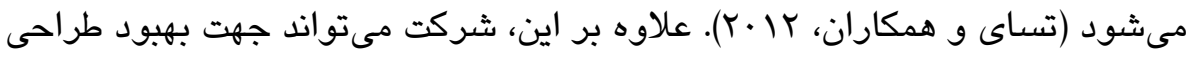

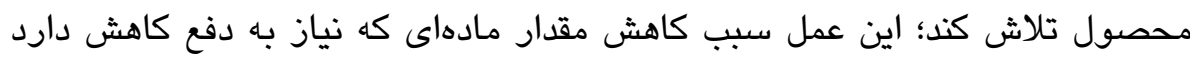

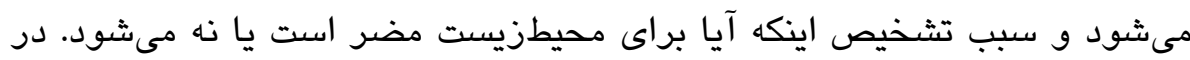

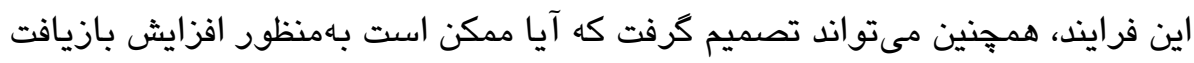

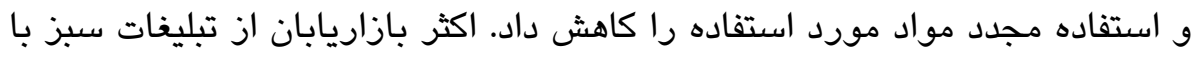

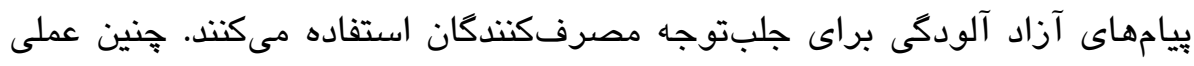
مىتواند دانش آنها را از محصولات و مسائل زيستمحيطى را افزايش دهائ دهد. در

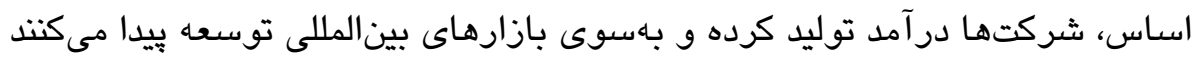

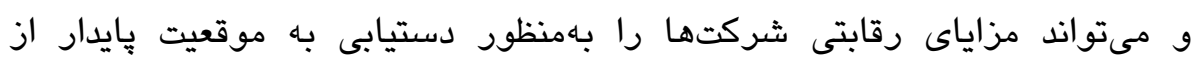

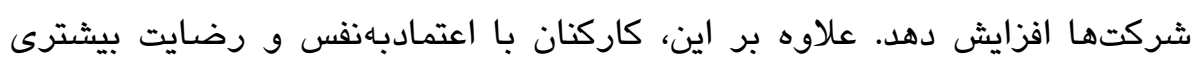

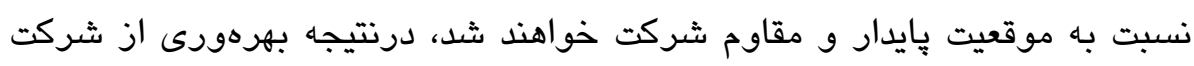

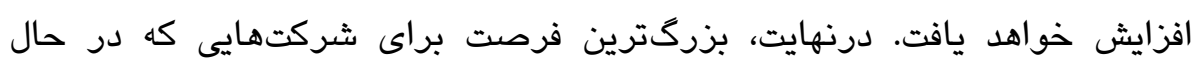

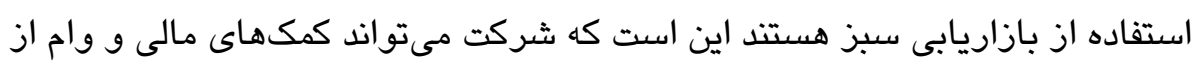

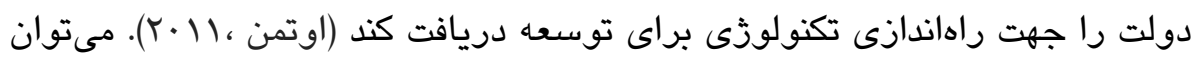

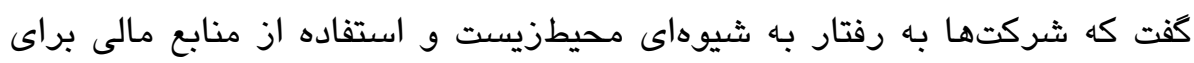

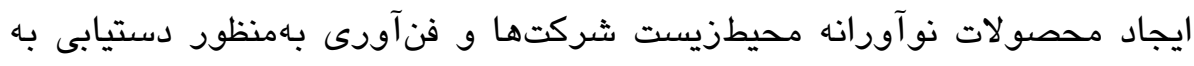

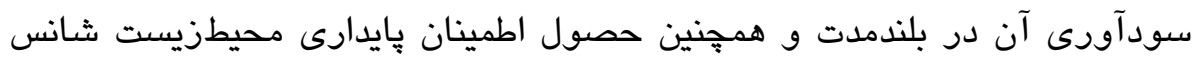

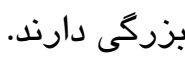

\section{عملكرد اقتصادى}

عملكرد يكى از مفاهيم بنيادين در مديريت محسوب مى شود كه بر جِّونكى انجام

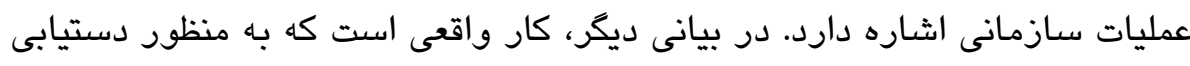

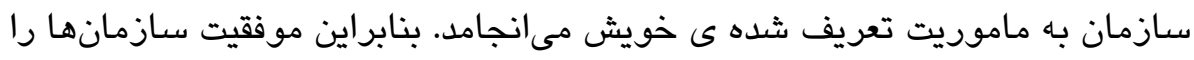

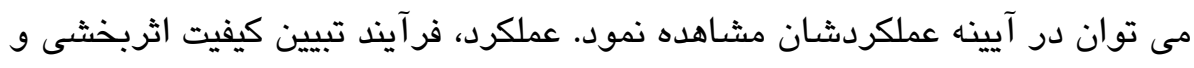
كارايى اقدامات كذشته تعريف مىشود. طبق اين تعريف عملكرد به دو جز تقسيم 
مىكردد: جزو اول، كارايى كه توصيف كنتده جگكونكى استفادهى سازمان از منابع در توليد محصولات و خدمات است و جزو دوم، اثربخشى كه توصيف كنتدهى درجه نيل

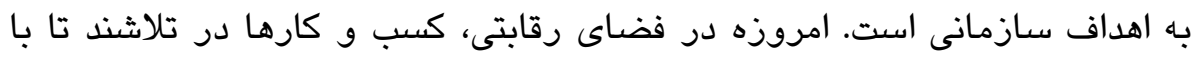

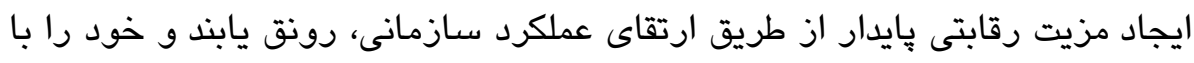

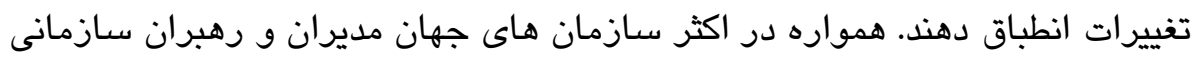

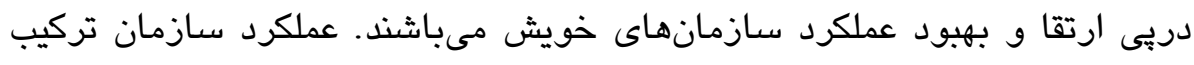

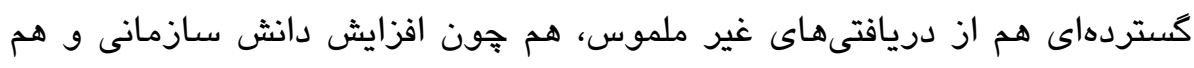

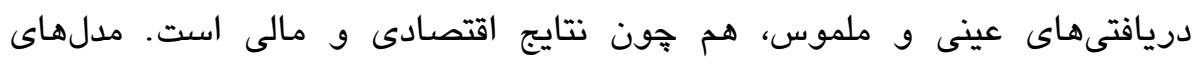

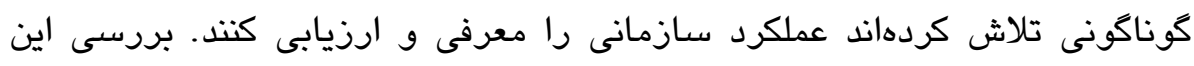

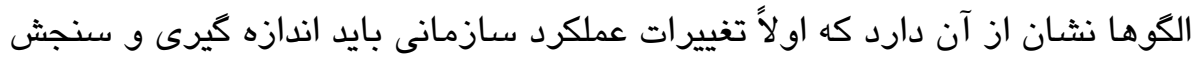

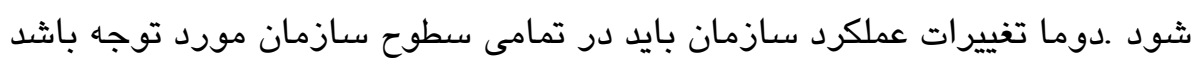

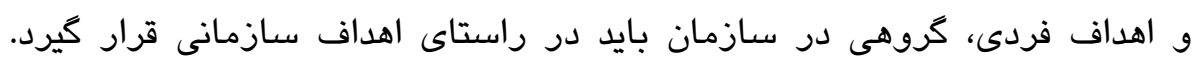

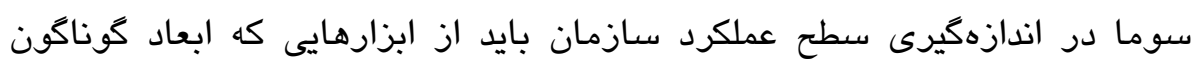

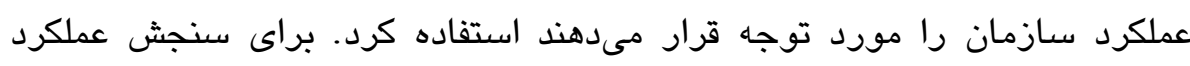

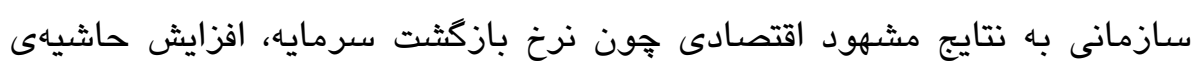
سود وسطح خلاقيت و نوآورى توجه كرد.

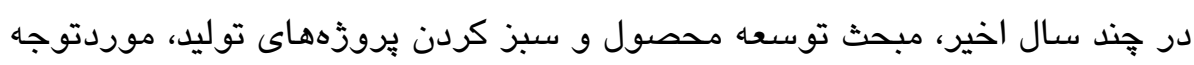

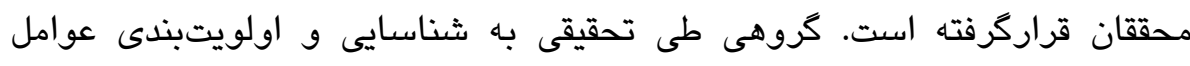

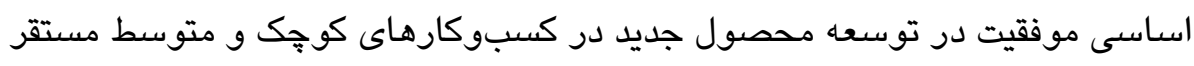

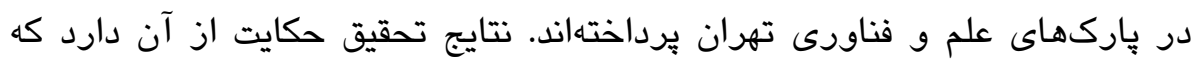

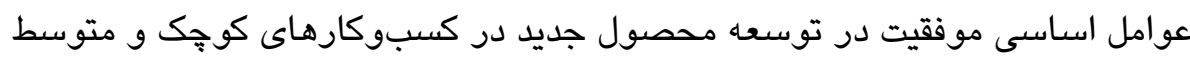

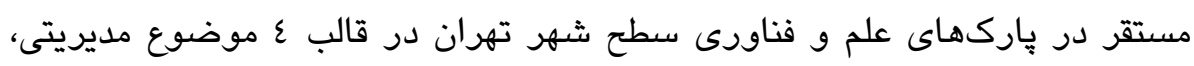

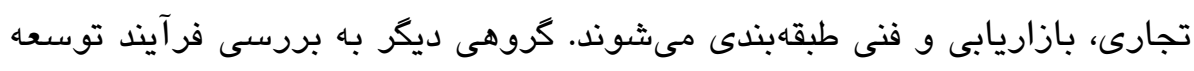

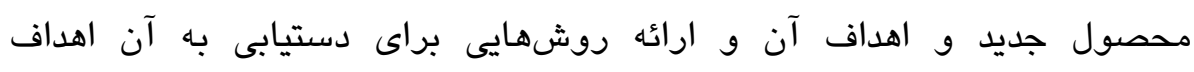

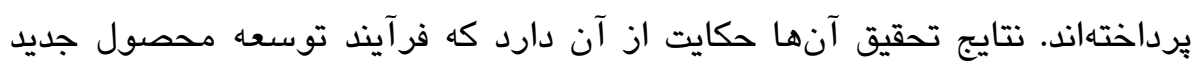

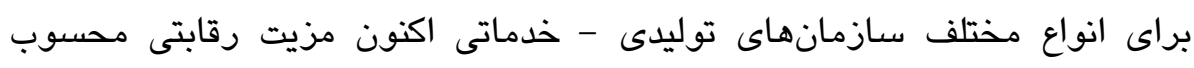

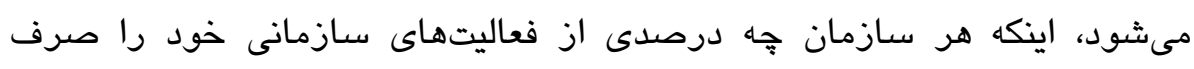

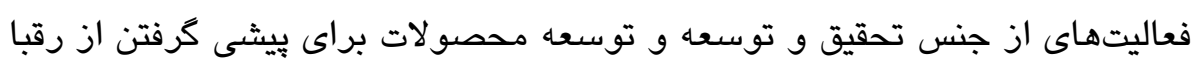


مىكند موضوعى است كه به جايكاه كنونى و استراتزيك سازمان در بازار تقاضا مربوط مىشود. همواره خواسته و نيازمندىهاى مشترى است كه عامل ترغيبكنتده

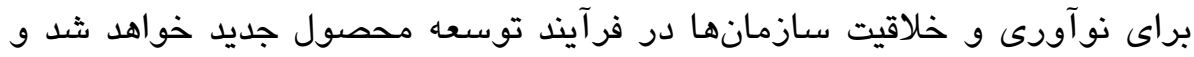
آنان را مجبور خواهد كرد كه در جهت حفظ مشتريان موجود و ترغيب مشتريان

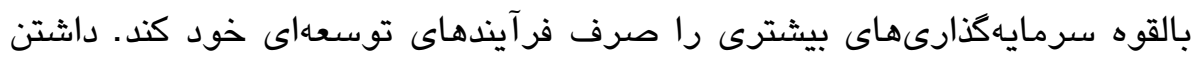
الكوى مناسب فرآيندى براى جنين سازمانهايى شرط اساسى و بيش برنده به

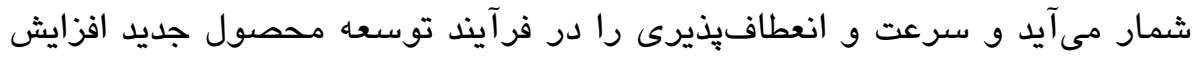

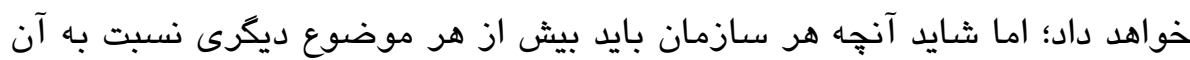

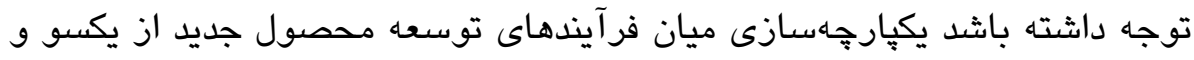

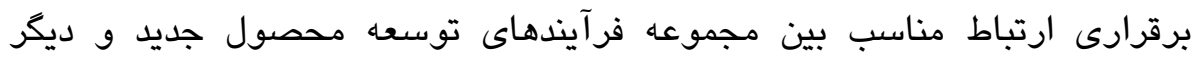

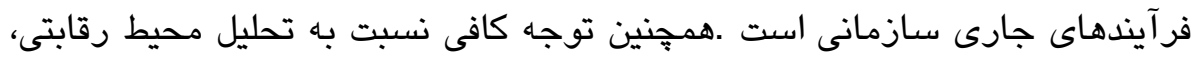

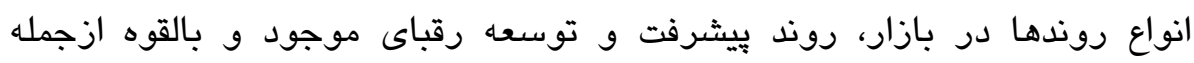

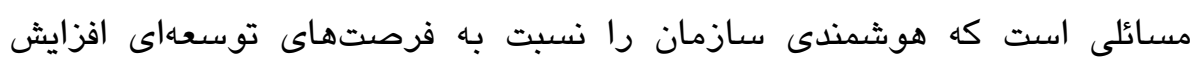
مىدهد و به بيشرو بودن سازمان كمك خواهد كرد. براون و ايزنهارت' (1990)

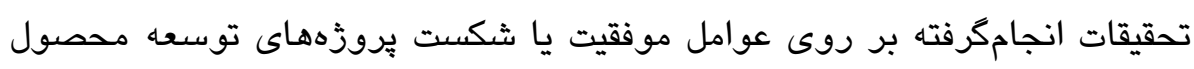

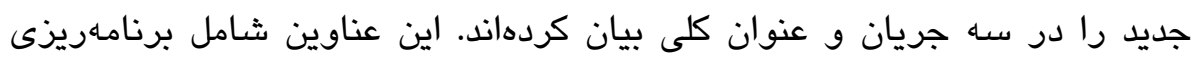

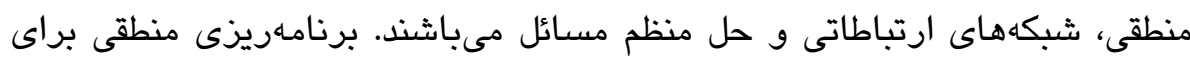

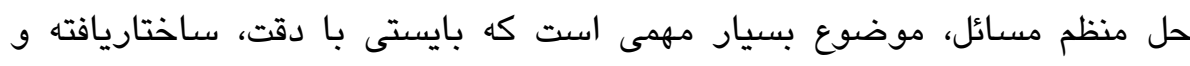

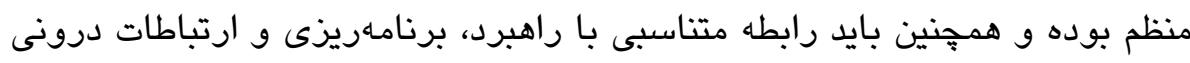

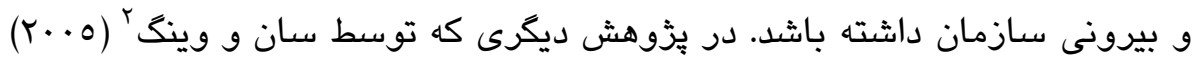

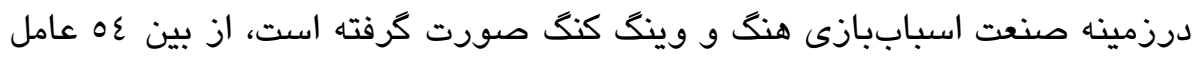

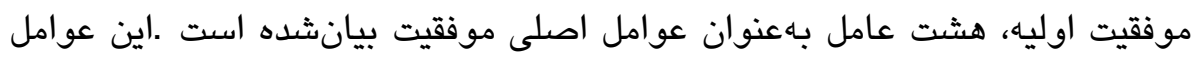

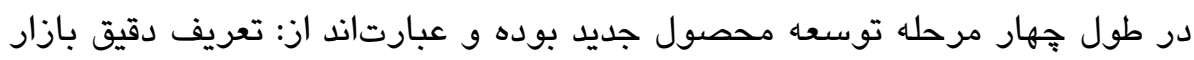

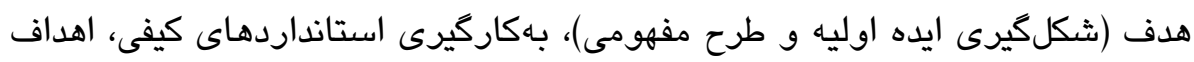

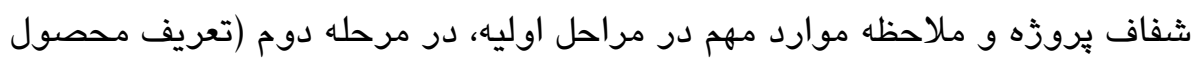

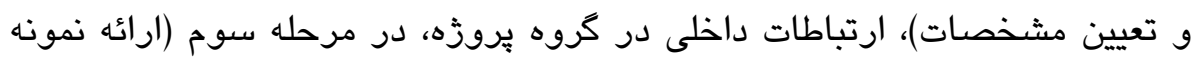

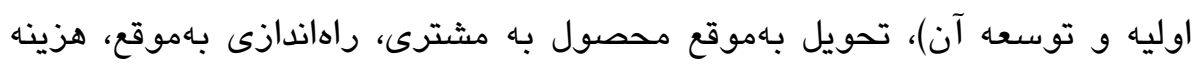

1- Brown\& Eisenhardt 
توليد محصول، در مرحله جهارم (تجارى كردن محصول). مو و همكاران' (Y. (Y)،

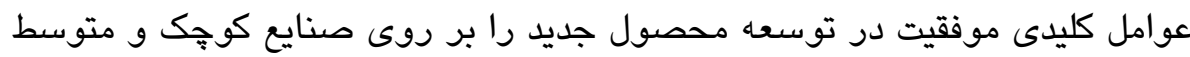

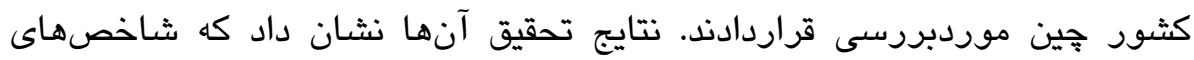

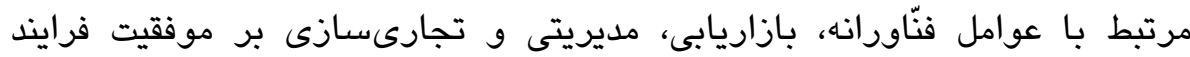

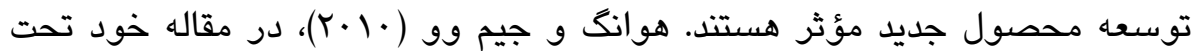
عنوان" اثر عوامل سازمانى بر موفقيت محصول جديد سبز، شواهدى از صنايع با

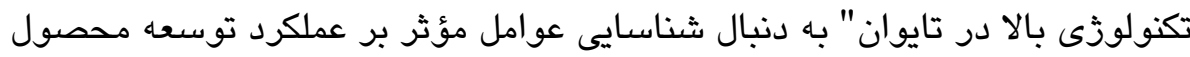

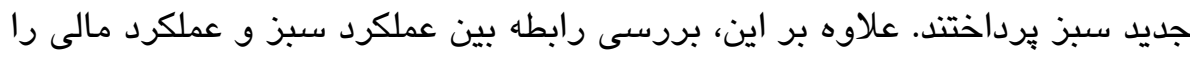

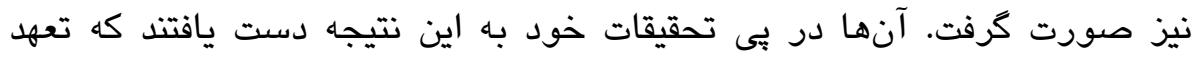

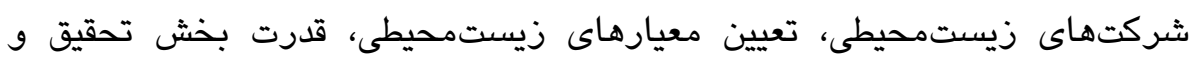

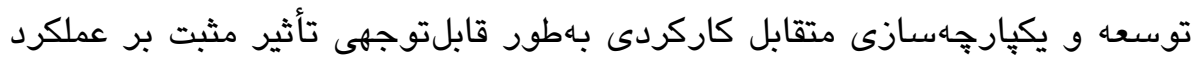

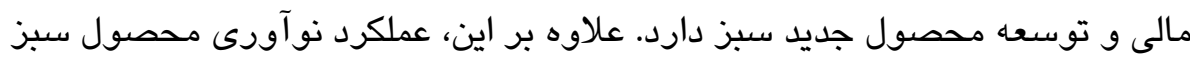

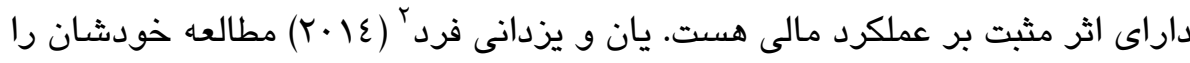

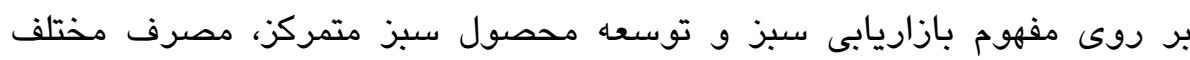

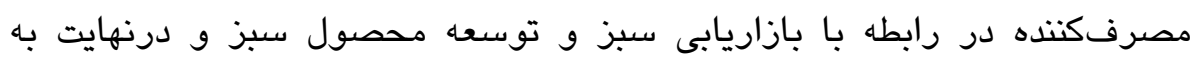

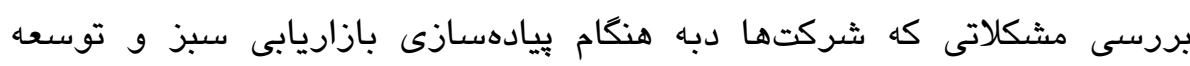

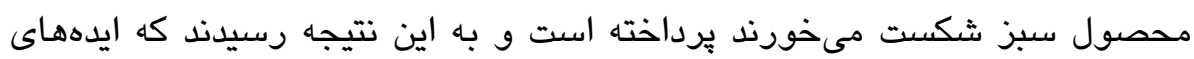

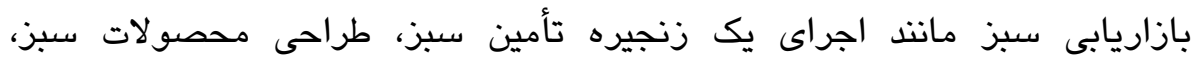

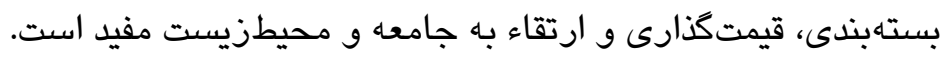

\section{روشناسى تحقيق}

يخزوهش حاضر در زمره يزوهشهاى كاربردى تعريف مىشود. تحقيقات كاربردى

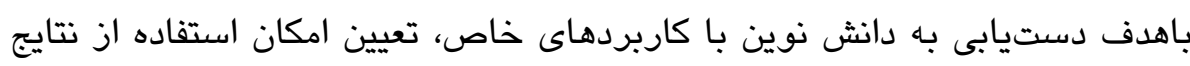

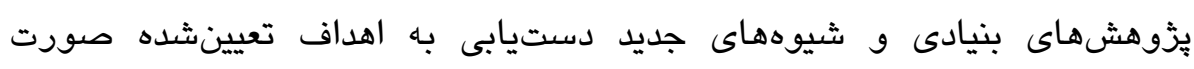

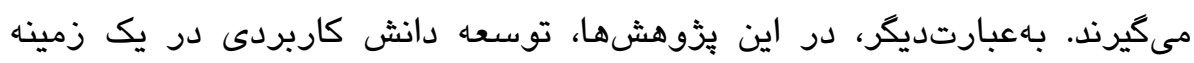

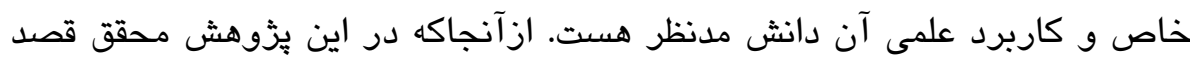

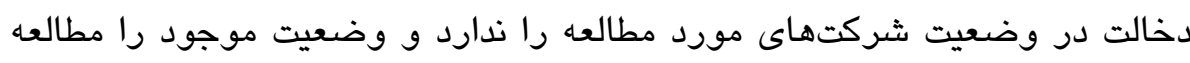

$1-\mathrm{Mu}$

2- Yan \& Yazdanifard 


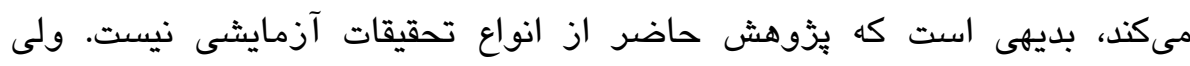

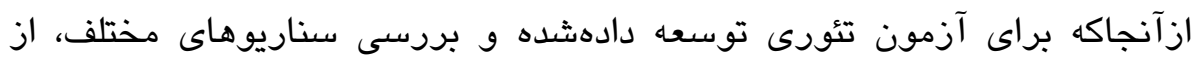

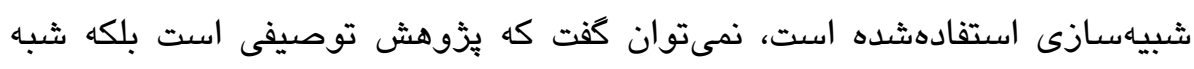
آزمايشى هست. در اين تحقيق ابتدا به شناسايى بهترين عوامل مؤثر بر توسعانه

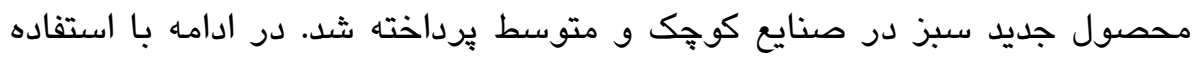

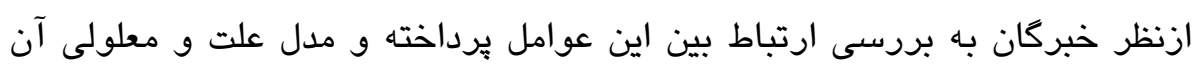

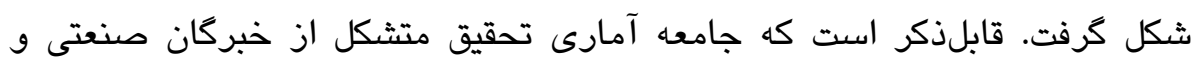

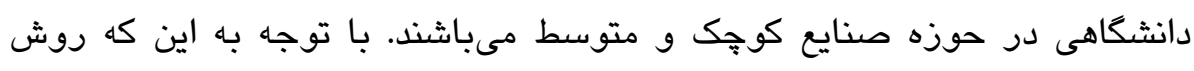

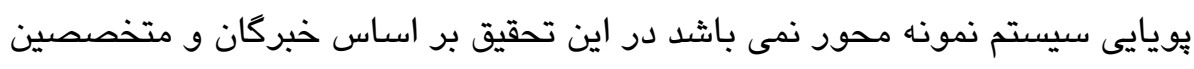

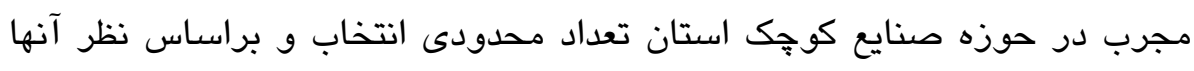

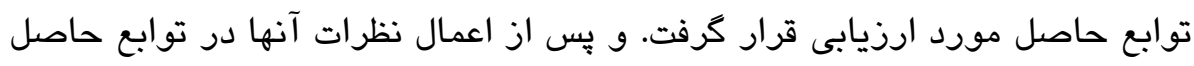

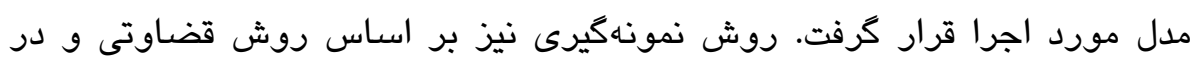

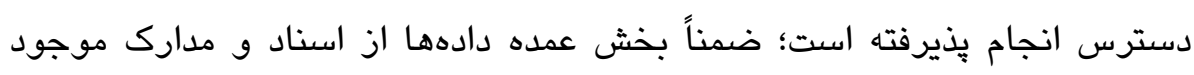
حاصلشده است و با توجه به اينكه روش تجزيهوتحليل دادها بـانيا يويايى سيستم

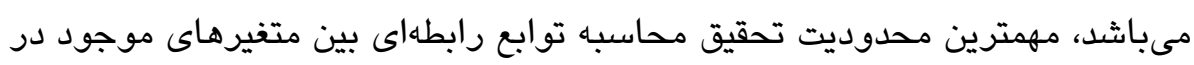

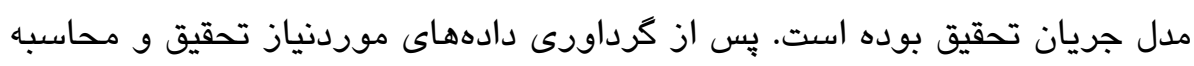

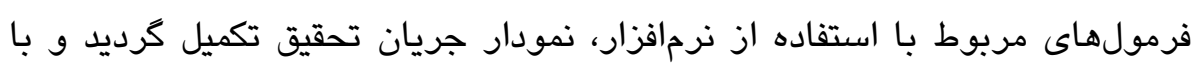

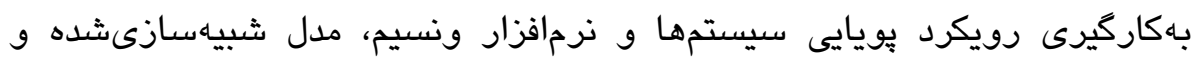

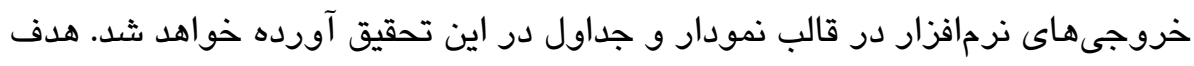

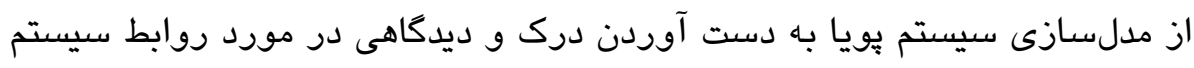

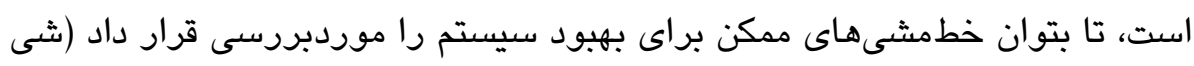

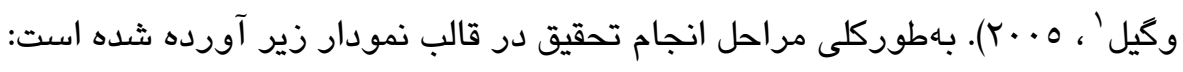




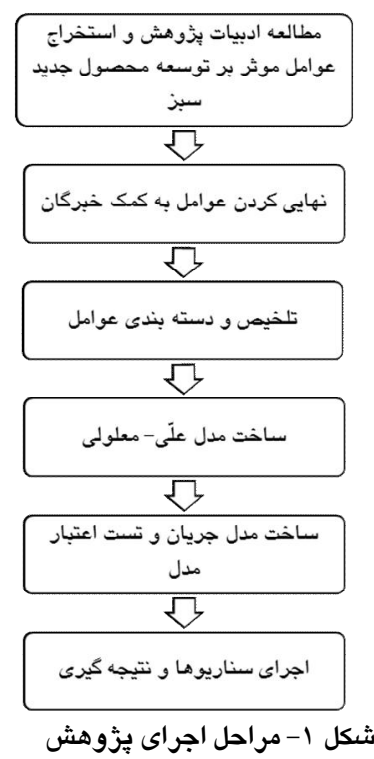

مدلسازى يويايىهاى سيستم

به علت تعاملات بين بخشهاى مختلف يك سيستم لازم است كه افراد تلاش كنت كه

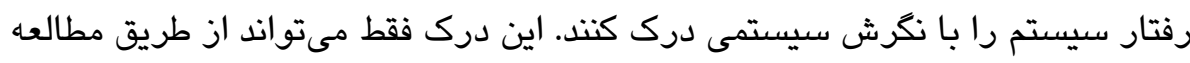

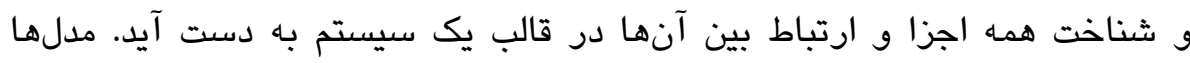

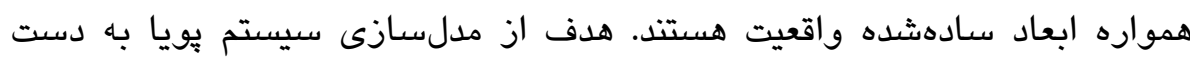

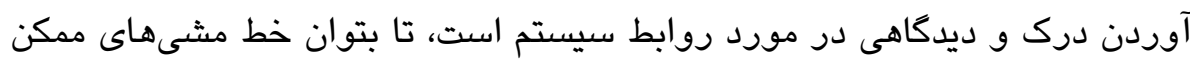

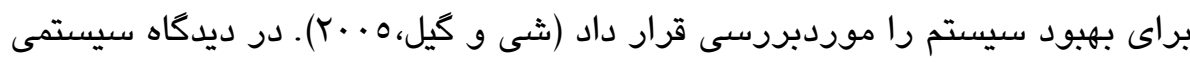
همه تصميمات در حلقههاى علت و معلولى بسته اتخاذ مىشيوند. هر مطالعهى يويايى سيستم سه مرحلهى اساسى دارد:

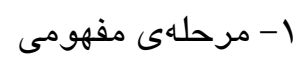

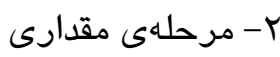

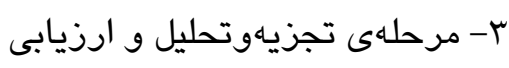
مرحلهى مفهومى داراى كامهاى زير است: 1- شناسايى مسئله r- تعيين هدف مدلسازى r- تعيين محدودهى بستهى سيستم ع- ساختار بازخورد 


\section{مراحل مدلسازى يويايىهاى سيستم}

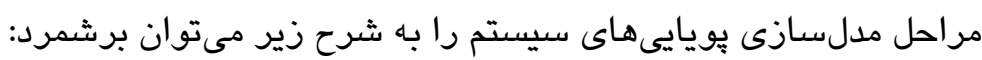

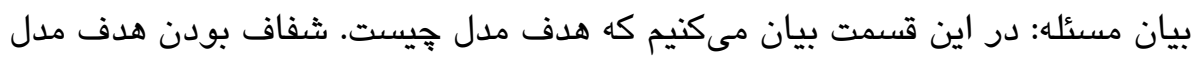

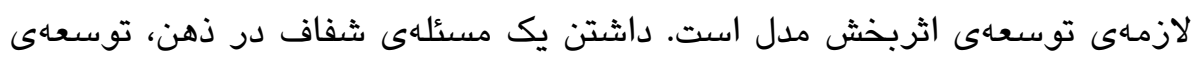

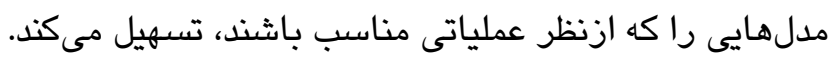

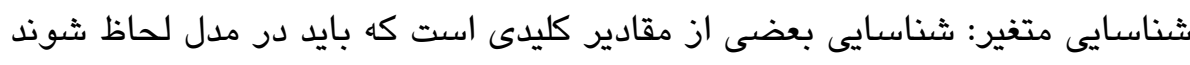

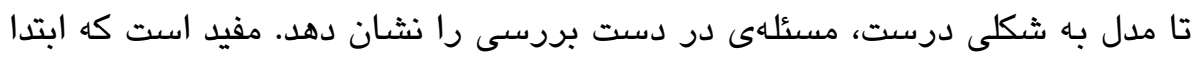

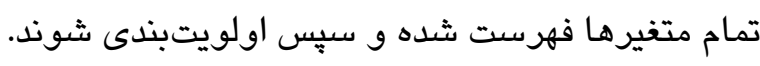

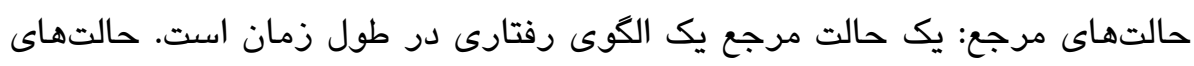

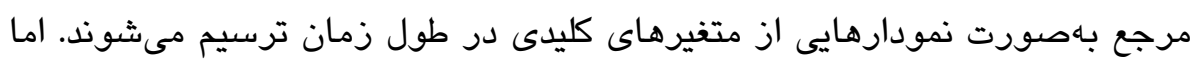

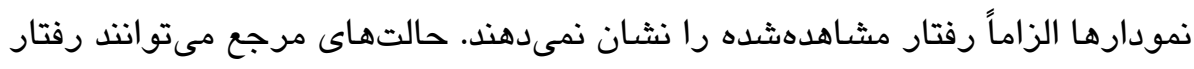
كذشته يا آينده را نثان دهند.

بررسى واقعيت: تعريف بعضى از صورتهاى بررسى واقعيت در رابطه بالينكه

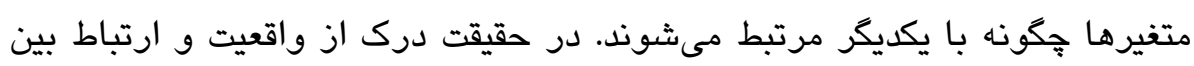

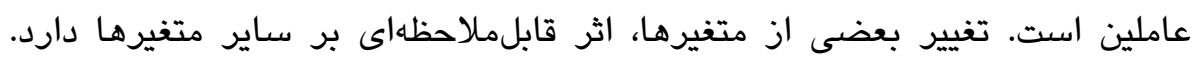

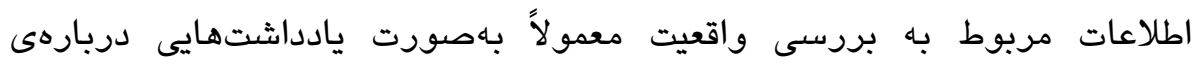

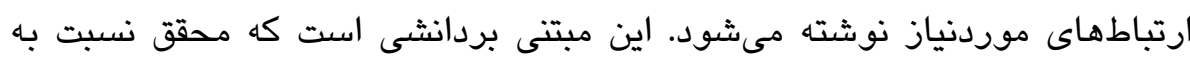
سيستم مورد مطالعه در اختيار دارد.

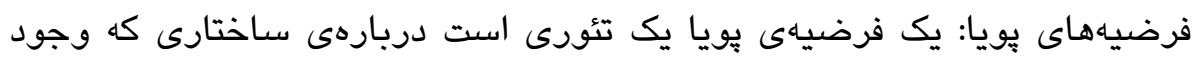

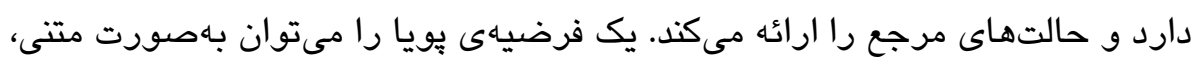

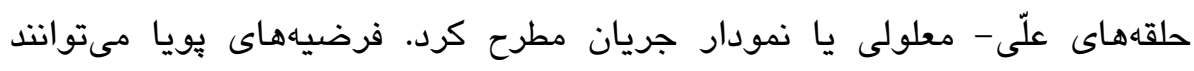

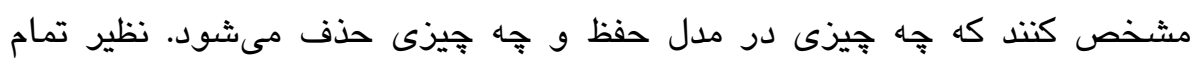

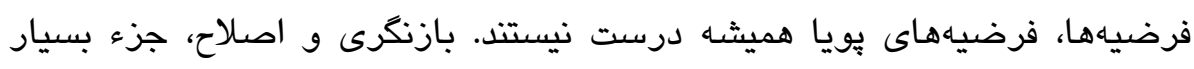
مهمى براى توسعاكى مدل خوب است.

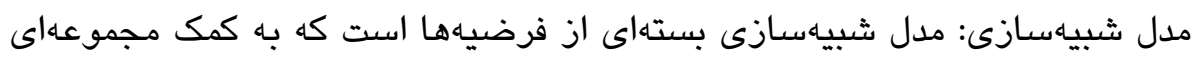

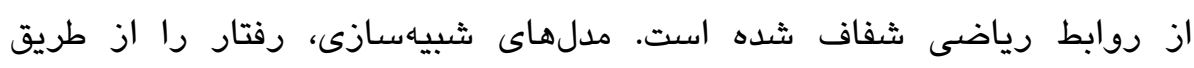

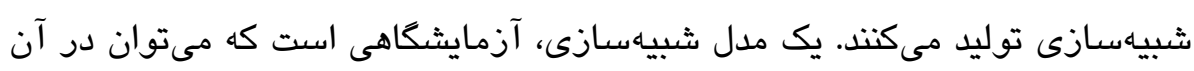
عناصر مختلف ساختار كه رفتار را تعيين مىكنتد، تجربه و درك كرد. 
فرايند بالا، فرايندى رفت و بركثتى و انعطافيذير است. همان طور كه روى يك

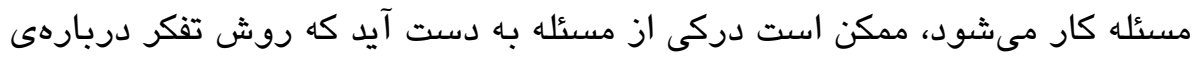
اجزا را تفيير دهد. تعريف صريح مرزهاى بين سيستم تحت مطالعه و محيط خارجىاش يك كام ضرورى از روش يويايى هاى سيستم است.

\section{مدل شبيه سازى توسعه محصول جديد سبز}

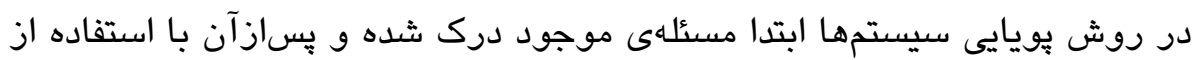

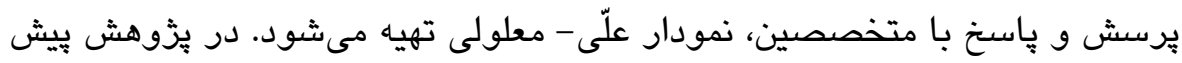

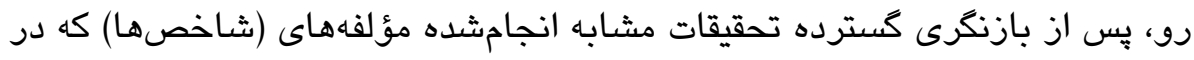

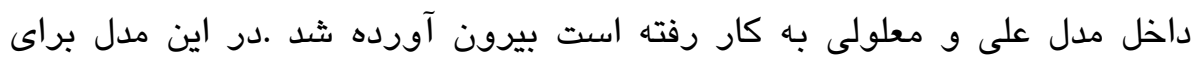

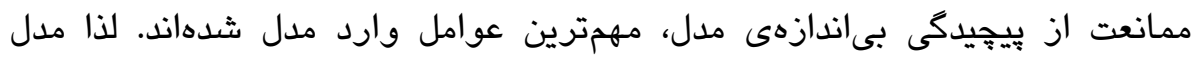
بهخوبى وضعيت سيستم و تعامل اجزاى كليدى آن با يكديكر را به تصوير مي مكثيد.

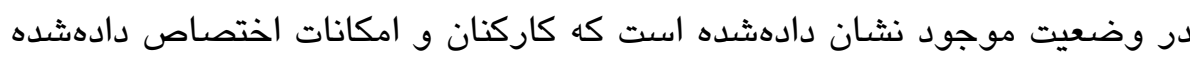

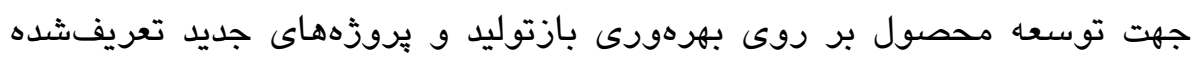

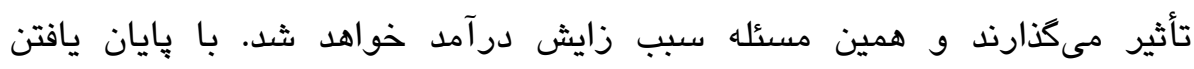

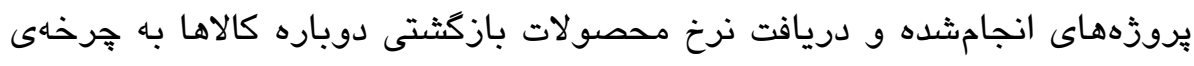

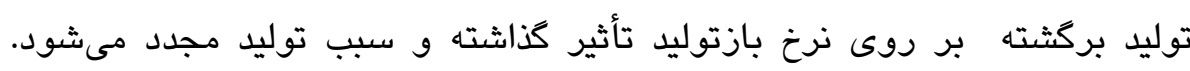

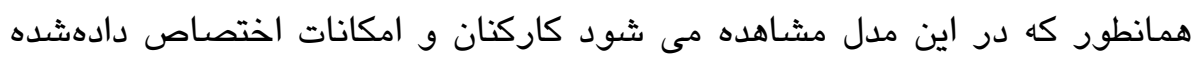
جهت توسعه محصول نقش بسيار مهمى در ايجاد در آمد بيشتر دارند.

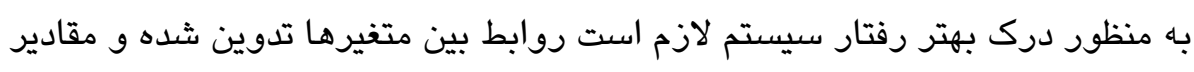

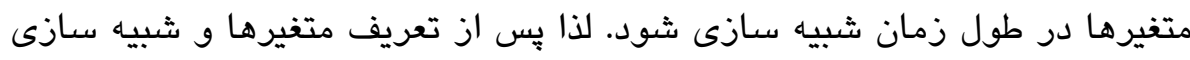

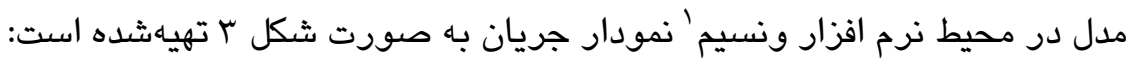




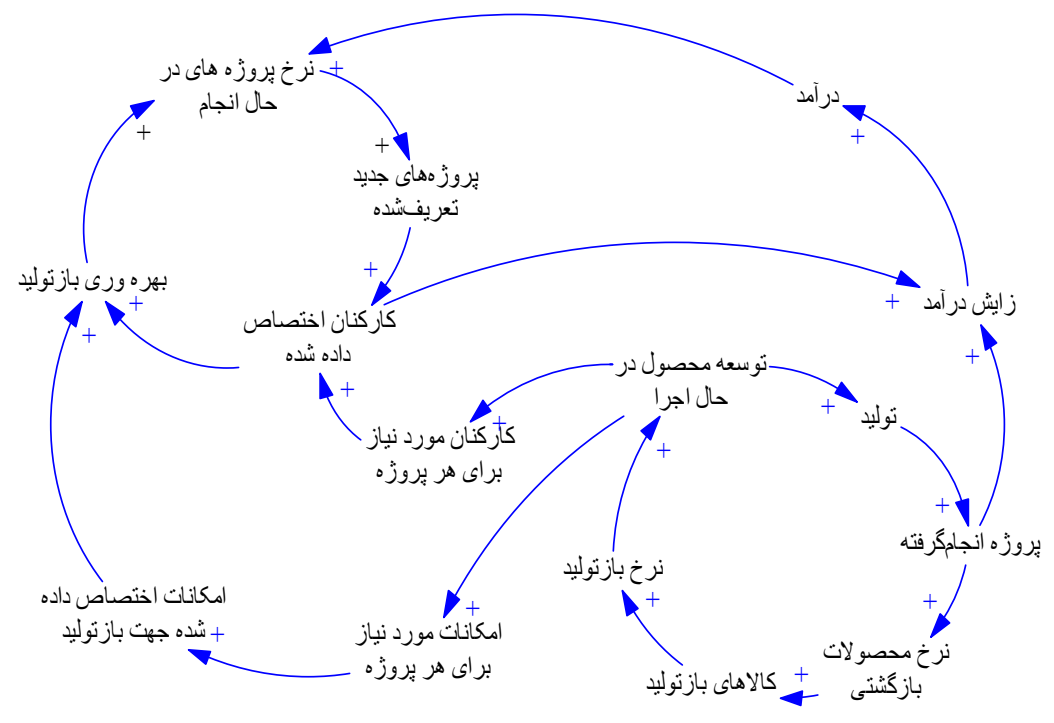

شكل ץ- مدل علّى - معلولى عوامل مؤثر بر توسعه محصول جديد سبز

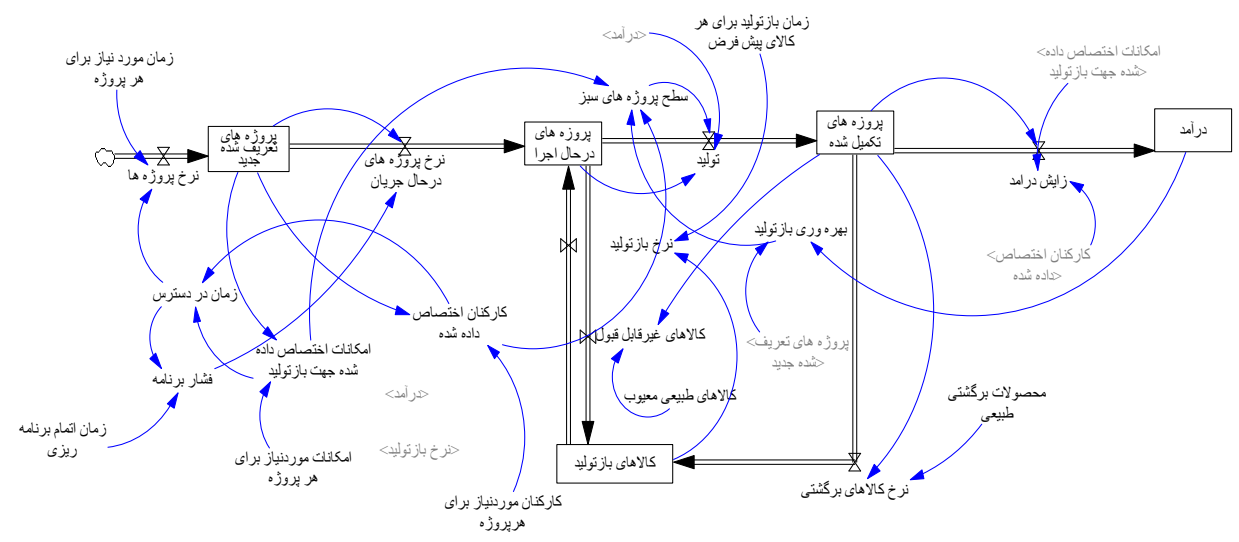

شكل r- مدل جريان مسئله يُخوهش 


\section{معادلات مدل يويايى سيستم}

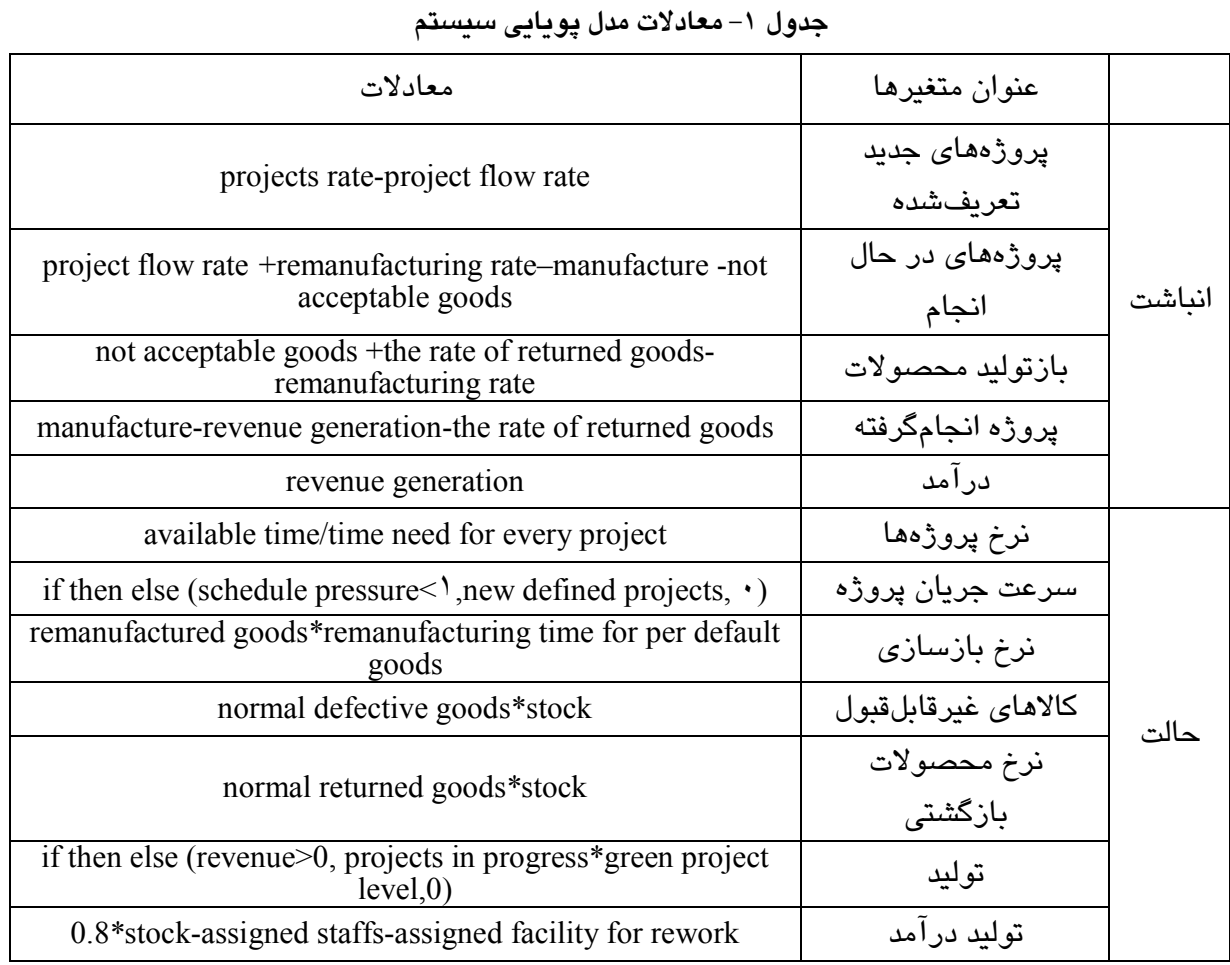

تجزيه و تحليل مدل

يس از جمع آورى اطلاعات از منابع كتابخانهاى و نظرخواهى از خبركان ارتباط بين

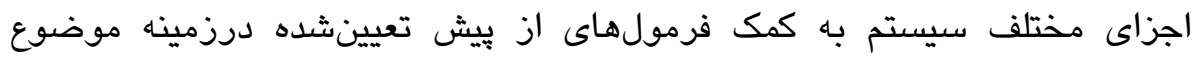

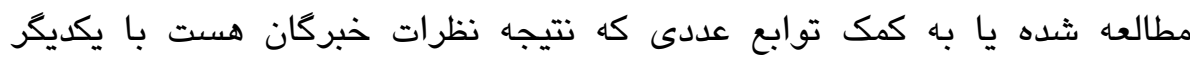
برقرارشده است و رفتار مدل مورد مشـاهده قراركرفته است.

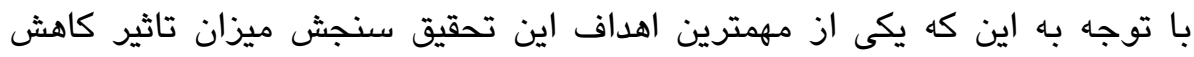

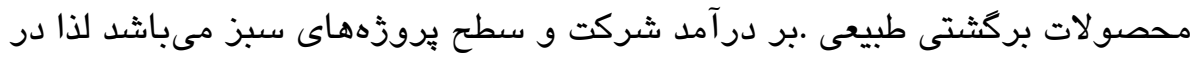

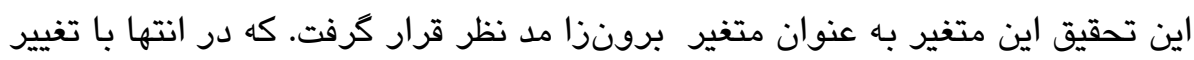

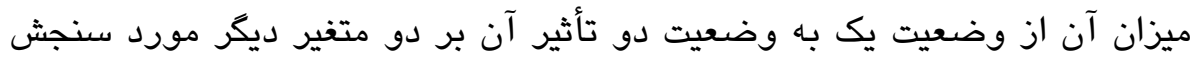

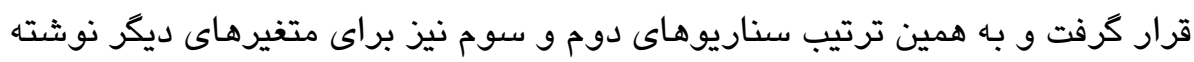
شد كه در ادامه هركدام به طور جداكانه توضيح داده شده است: 
سناريو (1): در اين سناريو، تأثير كاهش محصولات بركثتى طبيعى بر درآمد شركت

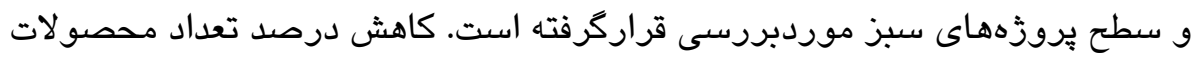

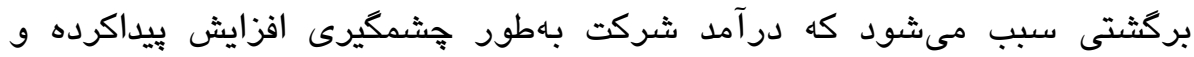
همجنين تأثير مثبتى بر روى سطح محصولات سبز دارد. بر اين اساس رفتار متغيرهاى كليدى مدل بِ از شبيهسازى در شكل ع نشان دادهثده است.

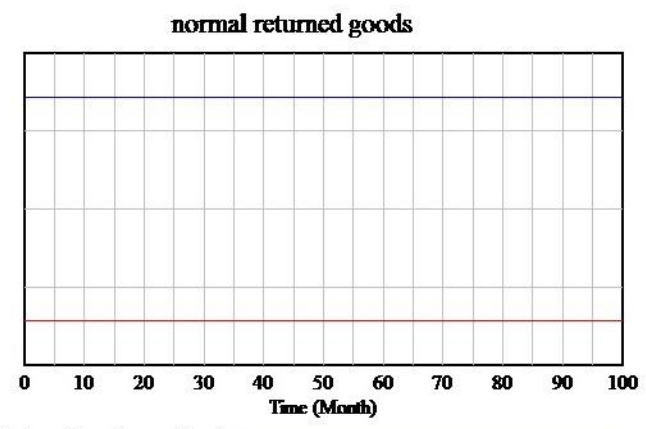
nomal retumed goods : condition 1
nomal retumed goods : condtion 2

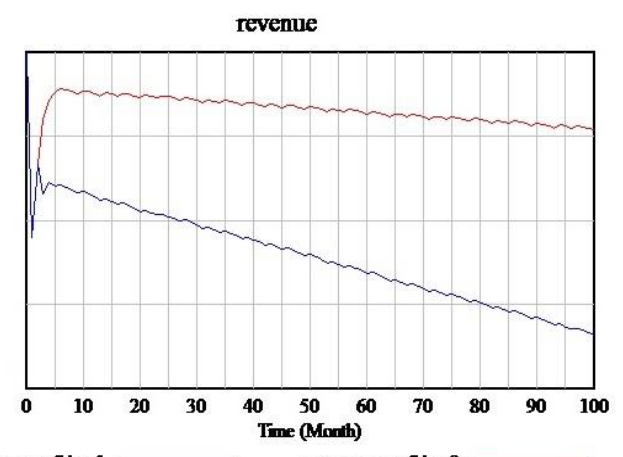

revene : conction 1

revenne : condtion 2

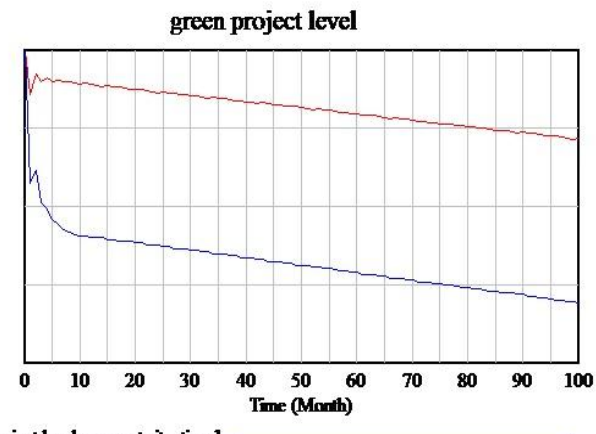

green project level : present sination 1 green project leved: present sinction 2

شكل ץ- رفتار متغيرهاى سطح بروزههاى سبز و درآمد شركت با توجه به كاهش تعداد محصولات بركشتى 
سناريو (Y): در اين سناريو، تأثير كاهش زمان اتمام برنامهريزى و زمان موردنياز

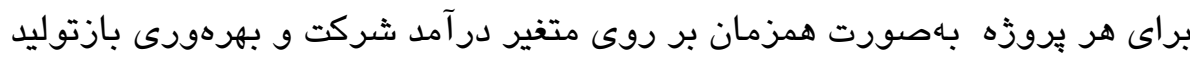

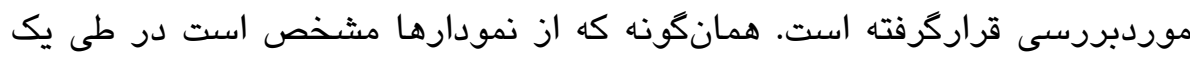

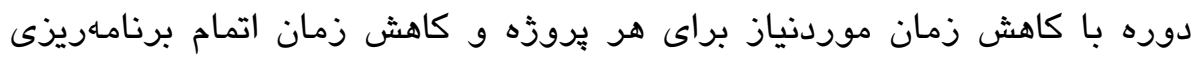

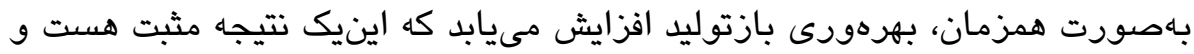

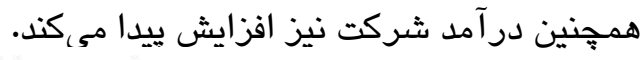
time need for every project

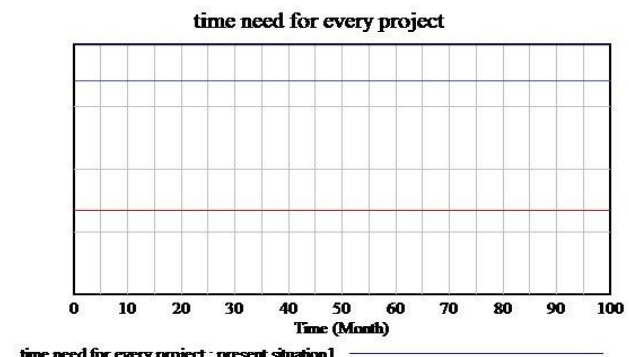

time need fir every project: presents sinationl

scheduled completion time

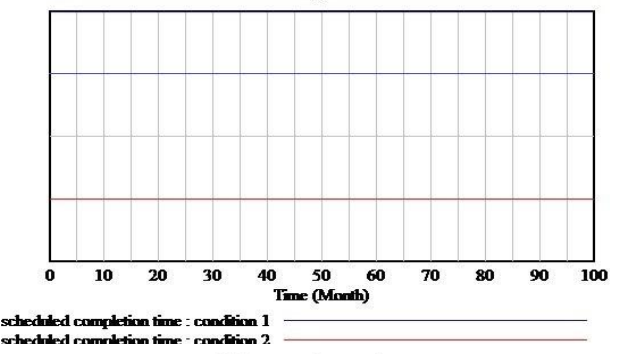

efficiency of rework

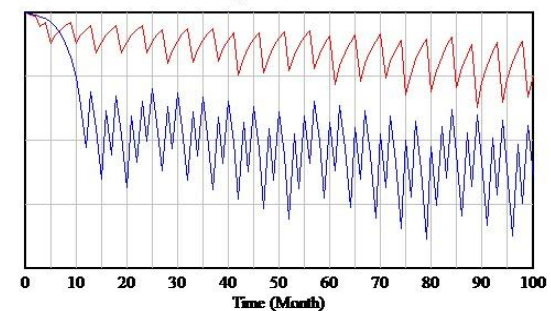

efficiency of rework: present situation 1

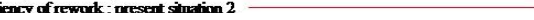

revenue

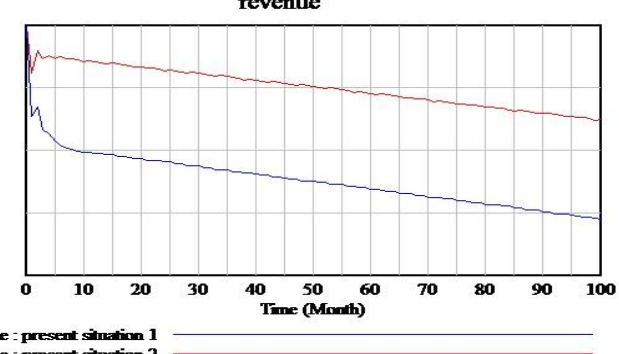

revene : present simation 1
revene : present simation 2

شكل ه-رفتار متغيرهاى بهرهورى بازتوليد و درآمد شركت با توجه به كاهش زمان اتمام برنامهريزى و

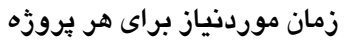


سناريو (ץ): اين سناريو بر آن است كه تأثير افزايش كاركنان و امكانات موردنياز

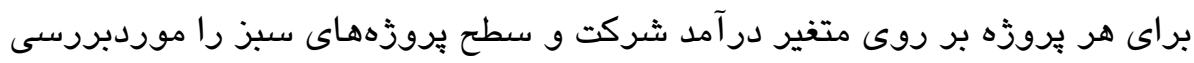

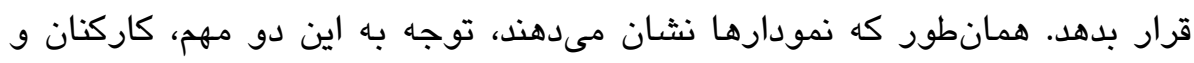

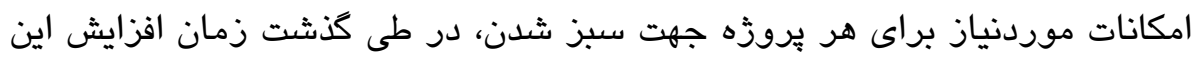

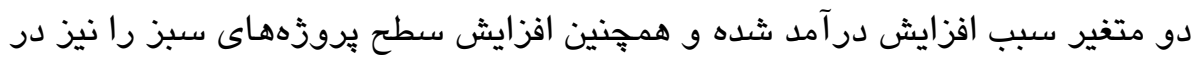

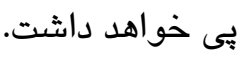

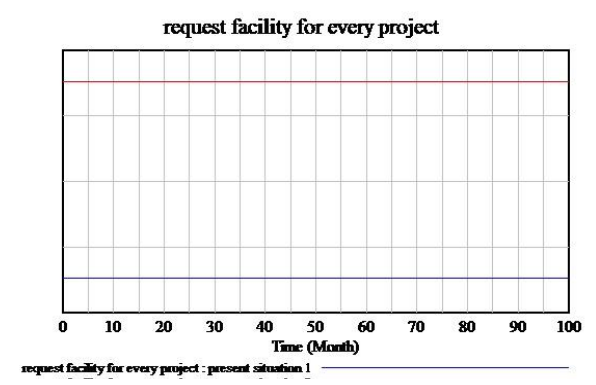

request staff for every project
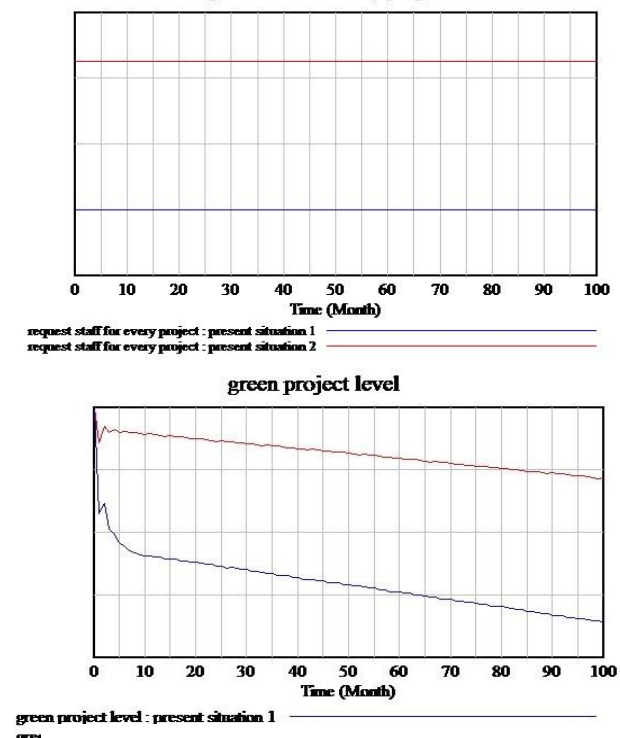

green

revenue

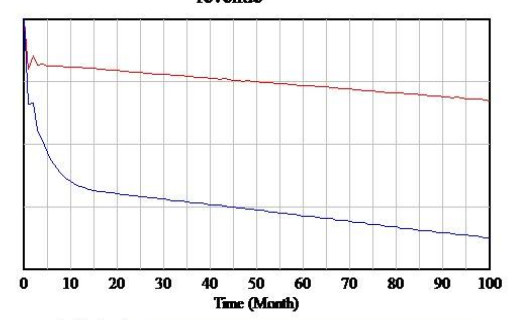

revene: present sination 1
revene : presest sitution 2

شكل צ- رفتار متغيرهاى سطح بروزههاى سبز و درآمد شركت با توجه به افزايش كاركنان و امكانات موردنياز براى هر بֶروزه 


\section{بحث و نتيجهكيرى}

يس از مطالعه و بررسى بِّوهشهاى بيشين در اين زمينه، عوامل مؤثر بر توسعه محصول جديد سبز شناسايىشده و با نظرخواهى از خبركان صنعت موردمطالعه،

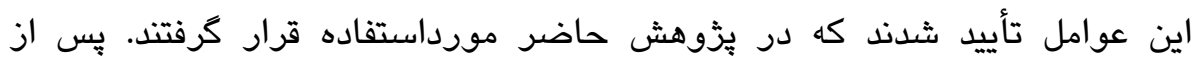
شناسايى مهمترين مؤلفهایى مؤثر بر توسعه محصول جديد سبز، با نظرخواهى از

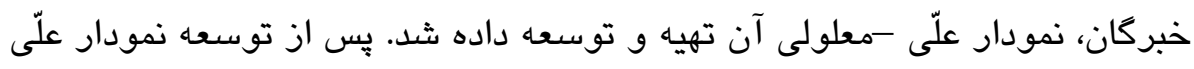

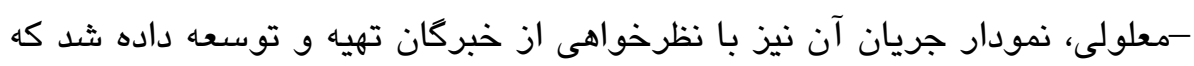
اين نمودار خود وضعيت موجود توسعه محصول جديد سبز را در صنايع كوجك و متوسط نشان مىدهد. با استفاده از نمودار جريان، سه سناريو موردبررسى قرار كرفت و رفتار متفيرهاى كليدى مدل، بر اساس سياستهاى مختلف مورد تجزيه و

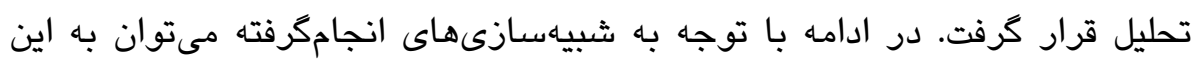
نتايج اشاره كرد: در اين يزوهش مشخص شد براى اينكه بهرهورى بازتوليد افزايش

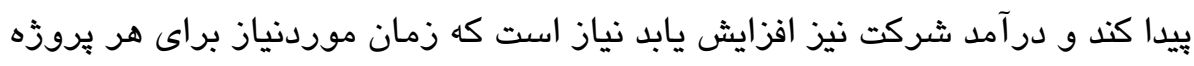

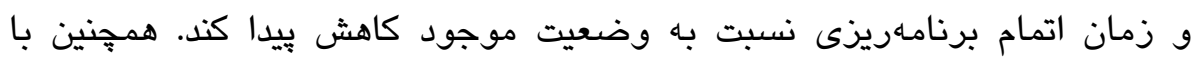
استفاده از مدل جريان به اين نتيجه دستيافتيم كه اكر كالاهاى بركگثتى طبيعى وهيت

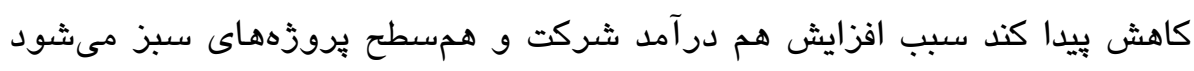

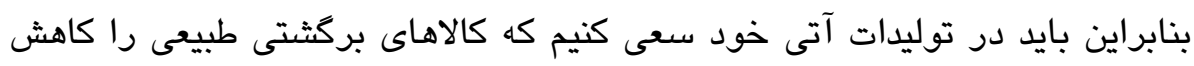

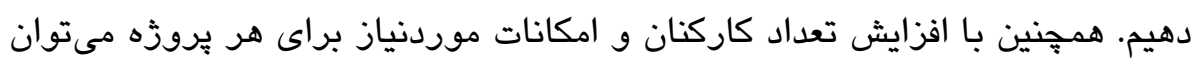
افزايش قابلملاحظهاى را در متغير درآمد و سطح بروزههاى سبز مشاهده نمود؛

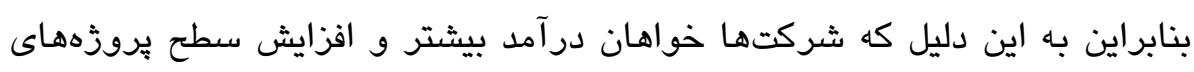
سبز بوده و خواهان بهرهورى بيشتر هستند بايد در آينده به عواملى جون زئ زمان

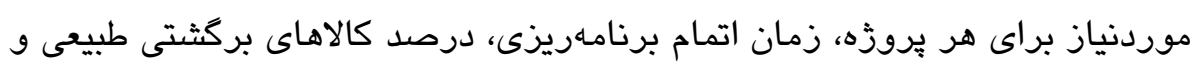

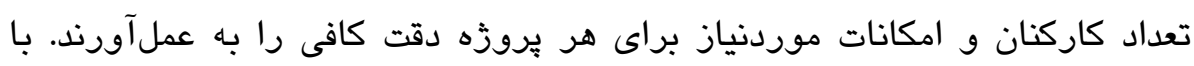
توجه به اينكه در اين بثروه باهنظور بررسى عوامل مؤثر بر توسعه محصول جديد سبز در صنايع كوجك و متوسط از يك مدل شبيهسازى استفادهشده است، مىتوان بدون هيج هزينهاى، متغيرهاى مختلف مدل را در تركيبهاى مختلف كه مىتواند 
حالات فوقالعاده زيادى را در بركيرد، تغيير داد و رفتارهاى ناشى از اين تغيير

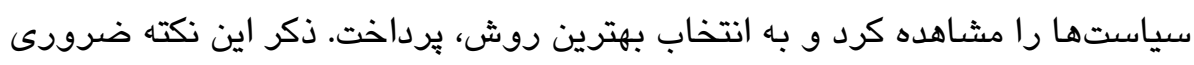

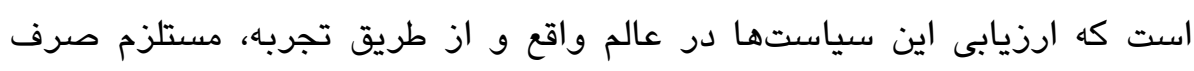
هزينهایى بسيار و زمان زيادى است كه موجب اتلاف منابع مىشود. حال آنكه با

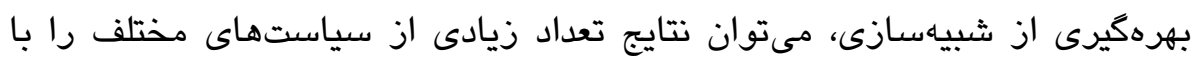
صرف زمان ناجيز و هزينهى اندك مورد ارزيابى قرار داد. لازم به ذكر است كه مدل

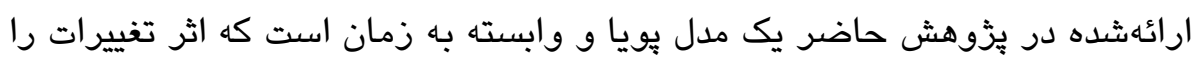
به روى مدل نشان مىدهد. از طرفى جون مدل ارائهده يك شبيهسازى از واقعيت است، بنابراين مىتوان ميزان تغييرات اعمالشده را در بخشهاى مختلف صنعت، مشاهده، محاسبه و بررسى نمود. در ادامه نتايج قابلارائه حاصل از اين بذّوهش

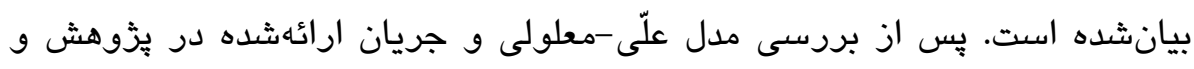
نظرخواهى از خبركان مشخص شد كه عواملى جون زمان موردنياز براى هر يروزه، زمان اتمام برنامهريزى، درصد كالاهاى بركثتى و تعداد كاركنان و امكانات

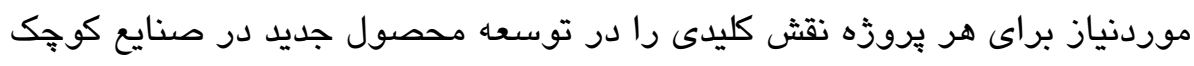

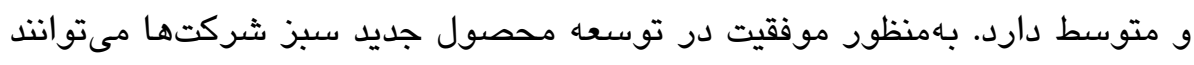
از طريق كاهش زمان موردنياز براى هر يروزه و همجنين كاهش زمان اتمام بروزهه،

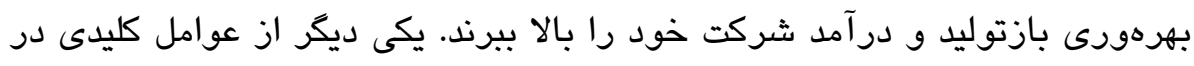
اين مدل، تعداد كاركنان و امكانات موردنياز براى هر بروزه است، با افزايش كاركنان

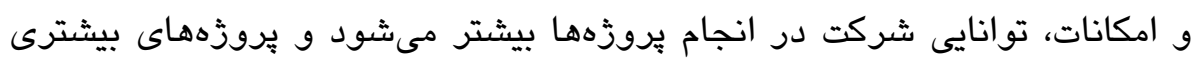

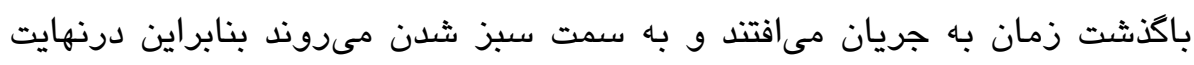
سبب افزايش درآمد، سطح بروزههاى سبز و حتى بهرهورى بازتوليد مىشئ ودي؛

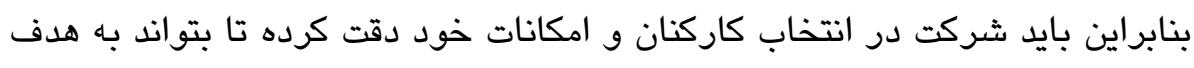

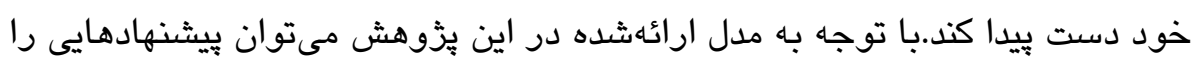
بدين شرح داد: مدل ارائهده را مىتوان با مقادير متفاوت متفيرهاى كليدى تست كرد

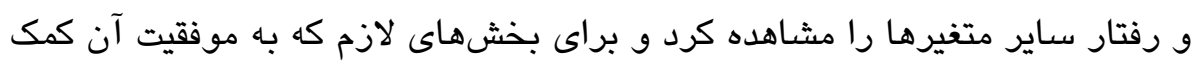
مىكند، برنامه عملياتى و راهبردى تدوين كرد. توجه به معيارهاى زمان موردنياز 


$$
\begin{aligned}
& \text { براى هر بروزه و زمان اتمام برنامـريزى براى هر كالا بايد مدنظر مديران صنايع }
\end{aligned}
$$

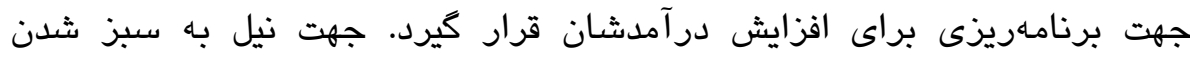

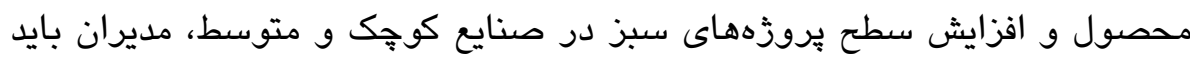

$$
\begin{aligned}
& \text { كاركنان و امكانات موردنياز براى هر بروزه را بهكونهاى در نظركيرند كه بتوانتد } \\
& \text { بالاترين درآمد را كسب كنتد. }
\end{aligned}
$$

1- Albino, V., Balice, A., \& Dangelico, R. M. (2009). Environmental strategies and green product development: an overview on sustainability-driven companies.Business Strategy and the Environment, 18(2), 83-96.

2- Ar, I. M. (2012). The impact of green product innovation on firm performance and competitive capability: the moderating role of managerial environmental concern. Procedia-Social and Behavioral Sciences, 62, 854-864.

3- Azar, A., \& Ardakani, D. (2014). Application of gray-based DEMATEL technique in designing of the aggregate green supply chain management's model. Uncertain Supply Chain Management, 2(3), 199-208.

4- Brown, S. L., \& Eisenhardt, K. M. (1995). Product development: Past research, present findings and future directions. Academy of Management Review, 20, 342 378.

5- Chen, C. (2001). Design for the environment: a quality-based model for green product development. Management Science, 47(2), 250-263.

6- Dangelico, R. M., \& Pujari, D. (2010). Mainstreaming green product innovation: Why and how companies integrate environmental sustainability. Journal of Business Ethics, 95(3), 471-486.

7- Driessen, P. H., Hillebrand, B., Kok, R. A., \& Verhallen, T. M. (2013). Green new product development: the pivotal role of product greenness. Engineering Management, IEEE Transactions on, 60(2), 315-326.

8- González, D. B. Q., \& Salvador, M. R. (2014). Dynamic Modeling in New Product Development: The Case of Knowledge Management Enablers in a Food Product. International Journal of System Dynamics Applications (IJSDA), 3(1), 111 134.

9- Huang, Y. C., \& Jim Wu, Y. C. (2010). The effects of organizational factors on green new product success: evidence from high-tech industries in Taiwan.Management Decision, 48(10), 1539-1567.

10- Jabbour, C. J. C., Jugend, D., de Sousa Jabbour, A. B. L., Gunasekaran, A., \& Latan, H. (2015). Green product development and performance of Brazilian firms: measuring the role of human and technical aspects. Journal of Cleaner Production, 87, 442-451.

11- Kowang, T. O., Long, C. S., \& Rasli, A. (2014). New Product Development Framework for Multinational Multi-locations based Organizations in South East Asia. Procedia-Social and Behavioral Sciences, 129, 68-74.

12- Lin, R. J., Tan, K. H., \& Geng, Y. (2013). Market demand, green product innovation, and firm performance: evidence from Vietnam motorcycle industry. Journal of Cleaner Production, 40, 101-107. 
13- Mangun, D., \& Thurston, D. L. (2002). Incorporating component reuse, remanufacture, and recycle into product portfolio design. Engineering Management, IEEE Transactions on, 49(4), 479-490.

14- Mu, J., Peng, G., \& Tan, Y. (2007). New product development in Chinese SMEs: Key success factors from a managerial perspective. International Journal of Emerging Markets, 2(2), 123-143.

15- Ottman, J. (2011). The new rules of green marketing: Strategies, tools, and inspiration for sustainable branding. Berrett-Koehler Publishers.

16- Ottman, J. A., Stafford, E. R., \& Hartman, C. L. (2006). Avoiding green marketing myopia: ways to improve consumer appeal for environmentally preferable products. Environment: Science and Policy for Sustainable Development, 48(5), 2236.

17- Pujari, D., Wright, G., \& Peattie, K. (2003). Green and competitive: influences on environmental new product development performance. Journal of Business Research, 56(8), 657-671.

18- Shi, T., \& Gill, R. (2005). Developing effective policies for the sustainable development of ecological agriculture in China: the case study of Jinshan County with a systems dynamics model. Ecological Economics, 53(2), 223-246.

19- Sun, H., \& Wing, W. C. (2005). Critical success factors for new product development in the Hong Kong toy industry. Technovation, 25(3), 293-303.

20- Tsai, C. C. (2012). A research on selecting criteria for new green product development project: taking Taiwan consumer electronics products as an example. Journal of Cleaner Production, 25, 106-115.

21- Tsai, M. T., Chuang, L. M., Chao, S. T., \& Chang, H. P. (2012). The effects assessment of firm environmental strategy and customer environmental conscious on green product development. Environ Monit Assess, 184, 4435-4447. doi: 10.1007/s10661-011-2275-4.

22- Wang, X., Chan, H. K., \& Li, D. (2015). A case study of an integrated fuzzy methodology for green product development. European Journal of Operational Research, 241(1), 212-223.

23- Wittayapoom, K. (2014). New Product Development, Accounting Information, and Internal Audits: A Proposed Integrative Framework. Procedia-Social and Behavioral Sciences, 148, 307-314.

24- Yan, Y. K., \& Yazdanifard, R. (2014). The concept of green marketing and green product development on consumer buying approach. Global Journal of Commerce and Management Perspective, 3, 33-38. 